\title{
The Foreign Exchange Exposures and Enterprise Risk Management: Evidence from Hospitality Industry in Taiwan
}

\author{
Hsiao, Chiu-Ming \\ Department of Finance, National Chung Cheng University, Taiwan \\ $\&$
}

National Yunlin University of Science and Technology, Taiwan

No.168, Sec. 1, University Rd., Min-Hsiung Township, Chia-yi County 621, Taiwan (R.O.C.)

E-mail: shiaucm@yahoo.com.tw.

Received: April 2, 2017 Accepted: May 17, $2017 \quad$ Published: June 1, 2017

doi:10.5296/ajfa.v9i1.11077 URL: http://dx.doi.org/10.5296/ajfa.v9i1.11077

\begin{abstract}
This paper adopts ARIMA model to explore the relationship between business performance and the fluctuation of exchange rate. The empirical results show that the impacts of the fluctuation of foreign exchange rate on the business performance of hotels are significant and different across currencies and the size of a hotel. Furthermore, based on the framework of Kim (2013), a modern portfolio theory proposed by Markowitz (1952) gives an optimal allocation of foreign exchange for a hotel's decision-makers, who would avoid exchange rate risk exposure and complete the construction of enterprise risk management system (ERM) to reduce losses.
\end{abstract}

Keywords: Foreign exchange exposures, modern portfolio theory, enterprise risk management, financial performances, ARIMA 


\section{Introduction}

Tourism can be thought as an integral industry that combines public and private sectors. Anderson and Getz (2009) discussed that the public sectors should make the tourism policies to stimulate the development of tourism and promote some non-profit-festivals to attract tourists. Likewise, the private sectors, such as in the field of transportation, communication, leisure, department, etc., should be integrated under the same goals to generate the profit from tourism-related businesses. The more the tourists and the longer they stay, the more revenue generates from the hospitality industry. In Candela and Figini (2011), they developed the tourism economics which is said to be a no-smokestack industry. From the economic point of view, tourism will create value from catering, hotels, aviation, transportation and many other related industries.

In 2013, Japanese Prime Minister Shinzo Abe implemented a policy combining fiscal expansion (i.e. quantitative easing) and structural reform in the hope of revitalizing Japan's domestic economy. Indeed, this so-called "Abenomics" has resulted in a significant growth in Japan's domestic economy. Nieh and Cho (2017) adopted the panel data analysis to investigate the relationship between foreign exchange rate and financial ratios of Taiwanese automobile and integrated circuit industries. They found when the Abenomics applied a policy of QE to instigate a sharp depreciation of the yen, the effects of the policies absolutely benefit to Japanese export industries. Accordingly, the impact of exchange rates on some industries becomes even more obvious and important, especially in the tourism industry while Japanese yen is depreciated in order to stimulate the economy. A depreciation of the exchange rate against other currencies will increase a country's international competitive advantage or exports. Implementing quantitative easing policy that caused the depreciation of Japanese yen increases Japan's foreign trade and also successfully leads the economy back to situation. Surprisingly, the tourism industry has gained the most benefits of all. This paper, therefore, wants to study the case and examine if the situation could as well apply to the tourism industry in Taiwan.

Oh (2005) addressed the causal relations between tourism growth and economic expansion for the Korean economy. He employed the Granger causality test and found that the Korean tourism industry is economic-driven. Kim, Chen and Jang (2006) examined the relationship between tourism expansion and economic development in Taiwan. They found a bi-directional causality between them. In other words, in Taiwan, tourism expansion and economic development reinforce each other. Min (2013) used panel data approach to test the tourism-led economic growth hypothesis. He found that the tourism-led growth hypothesis is more strongly supported when the time-specific effects are eliminated, which will cause a biased estimate in the Granger causality test.

According to the data of the World Tourism Organization, the number of international tourist visited in Taiwan in 2012 was estimated 9.91 million, ranked the world's 31 and createdrevenues $\$ 14.7$ billion. In 2014 , Taiwan inbound tourists grew $23.6 \%$, ranked the $2^{\text {nd }}$ place of the world's top 50 tourist destinations, only less than of Japan's growth rate $29.4 \%$. Tourism revenue has growth $18.9 \%$, ranked the $4^{\text {th }}$ place in the world's top 50 tourism 
revenue areas. Gradually, Taiwan's tourism has been recognized considerable potential. Po and Huang (2008) used 88 cross-sectional countries' data to investigate the nexus between tourism development and economic growth. They found a significantly positive relationship of them when the proportion of tourism receipts in GDP is either less than $4.05 \%$ or more than $4.73 \%$, but not when it lies between these two ratios. Moreover, Chen and Song Zan (2009) showed that the tourism industry is greatly contributed to Taiwan's economy. In other words, Taiwan is a tourism-led economy.

Taiwan authority has opened to Chinese tourists since the summer of 2008. In order to increase the number of tourists, Taiwanese government has undertaken a number of initiatives to promote the tourism industry, such as Doubling Tourist Arrivals Plan (DTAP) introduced in 2002, Challenge 2008, Taiwan's 2015-2018 Tourism Action Plan, Mid-term Plan for Construction of Major Scenic Sites(2012-2015),Project Vanguard for Excellence in Tourism, and Tour Taiwan and Experience the Centennial. According to Taiwan Tourism Bureau, these plans are proposed to deepen the "Time for Taiwan" core promotional programs, implement "quality, uniqueness, intelligence, and sustainability" as strategies toward the goals of "development of international tourism, enhancement of domestic travel quality, and increased foreign-exchange revenues" to bring Taiwan's new tourism allure to the attention of the world ${ }^{1}$. Portnov and Li (2013) suggested that in order to achieve a greater stability in the number of inbound tourist arrivals, Taiwan should diversify sources of their inbound tourism, by giving priority to neighboring countries with relatively larger, more productive, and more steadily growing economies, such as China, Malaysia, or the other emerging countries.

According to Taiwan Tourism Bureau, the inbound number of tourists was 2,624,037 in 2000, 9,910,204in 2014 and over 10 million in the end of 2015. This tendency shows the visibility and attractiveness of international tourists traveling to Taiwan. Moreover, Taiwan's foreign exchange earnings generated by tourism leaped from $\$ 3,738$ million in 2000 to $\$ 14,615$ million in 2014, which its share in total GDP reached $2.76 \%$ from $1.13 \%$.It shows that Taiwan tourism industry earns a large part of foreign exchange earnings. The fluctuation in exchange rates for Taiwan's tourism industry is an important factor for Taiwan's overall economic development. The recent ten-year annual revenues generated from tourism, foreign exchange and domestic tourism are shown in Figure 1. The highest line is the tourism revenue (in red), which grows rapidly in 2009 due to the effect of opening of Chinese tourists to visit Taiwan. The lowest line is the domestic tourism revenue (in purple), which attains the maximum (331 billion of NT dollars) in 2011 and declines in the following years. The foreign exchange earnings (in green) smoothly increases in years.

${ }^{1}$ http://admin.taiwan.net.tw/public/public_en.aspx?no=6. 


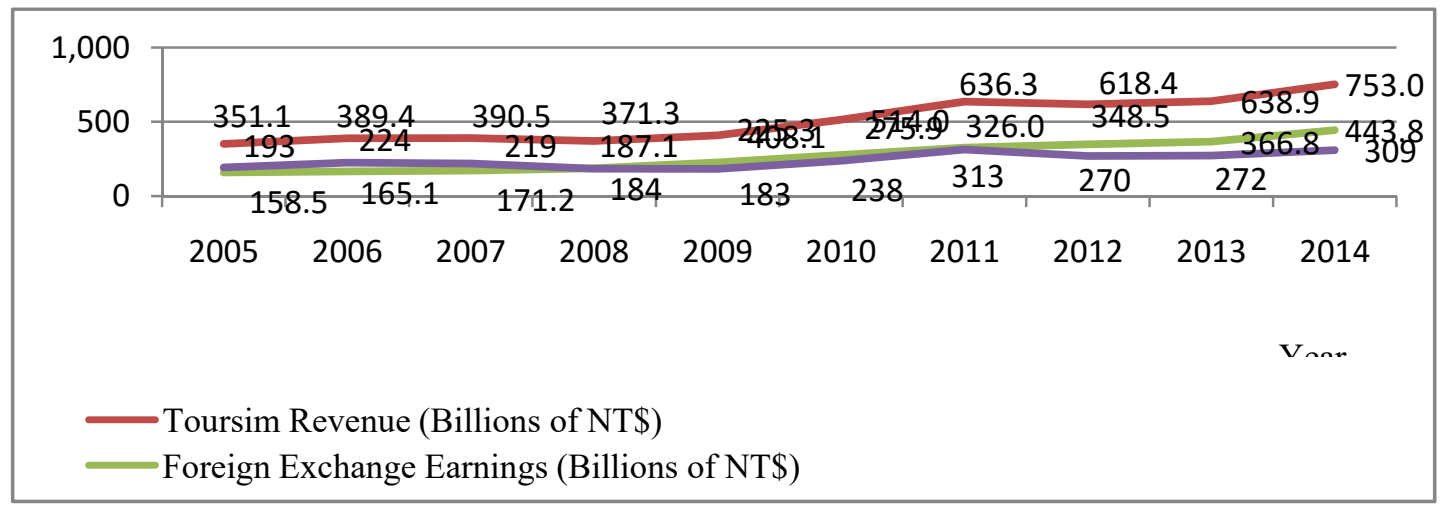

Figure 1. Revenues generate from tourism and foreign exchange

Source: Tourism Bureau, M.O.T.C., Republic of China (Taiwan).

Taiwan's tourism revenues have increased in recent years. The hotel industry plays an important role in the tourism industry, resulting in a huge source of foreign exchange earnings. Among the tourists, the number of Chinese tourists accounted for the largest part of all, followed by Japanese, European and the United States. Bilateral trade between Taiwan and China, Japan, Europe and the United States, respectively, is not only very close, but also represents the effect of the changes in exchange rates. The number of tourists traveling to Taiwan contributes the foreign exchange earnings.

Pritamani, Shome and Singal (2005) divided the U.S. companies into five categories and found that neither exporters nor multinational firms were the most affected by changes in exchange rates. The firms that suffered most from exchange rate fluctuations were wholly domestic U.S. companies facing foreign competition. Taiwan's hotel industry has the same situation. Based on the above point of view, we mainly discuss Taiwan's hotel industry for exposure to foreign exchange fluctuations and corporate risk management. Through our study, it suggests the hedging strategies to the decision-makers of firms and then to enhance Taiwan's hotel industry's risk management.

The structure of this study is as follows: Section 2 is literature review and methodologies will be discussed in Section 3; data collection and its statistical descriptions are in Section 4. The empirical results and analysis are shown in Section 5. The last section is the conclusion.

\section{Literature Review}

From the 1980s, there are numerous studies to discuss the foreign exchange exposures. The landmark papers, Dumas (1978), Adler and Dumas (1980) and then Hodder (1982) implemented the change of foreign exchange rates into the regression models to study the U.S. multinational firm's values. And Jorion $(1990,1991)$ followed their studies and found that the stock returns of U.S. multinational firm are significantly positively correlated to the volatility of the U.S. dollar. Moreover, Bodnar and Gentry (1993) studied the different effects of the fluctuations of foreign exchange rates on the different industries in U.S., Canada and Japan. Schnabel $(1989,1994)$ extended the Adler-Dumas model to a multi-factor model by including several currencies exchange rate movement. 
Moreover, He and Ng (1998) studied Japan 171 multinational firms there are about 25\% firm's stock returns significantly positively correlated to the foreign exchange exposures, themselves. And the effects are increasing as firm's size increases. Morelli (2007) found the same effects of firm's size on the UK listed firms' stock returns. Dominguez and Tesar (2006) examined the relationship between exchange rate movement and firm value. No matter in the firm- or industry-level, they found that the foreign exchange exposure do affect the value of firm. Salifu, Osei, and Adjasi, (2007) examined the foreign exchange exposure of Ghanaian listed companies. Their results showed that about 55\% companies are exposed to the fluctuation of US dollar and 35\% companies are exposed to that of UK pound. Moreover, Chen and Kuo (2016) found that the exchange rate variability was significantly related to foreign reserves foreign reserves growth rate and the stock index return. Jahan (2016) studied the efficiency of using currency derivatives to reduce the effect of currency fluctuations on the performances of the Advanced Chemical Industries in Bangladesh.

On the other hand, Maloney (1990) and Koo (1994) paid attention on the Australian mining industry. They indicated that the fluctuations of the exchange rates between Australia dollars against to the major currencies will affect the firm's profit. So they suggested that firm should find some strategies to manage the positions of foreign currencies in order to avoid the losses caused by the fluctuations of exchange rates and then reduce the firm's performance. Aggarwal and Harper, (2010) investigated the foreign exchange exposures that U.S. domestic companies faced to. Their results showed that the domestic company suffers more foreign exchange exposures than MNEs. They concluded that the MNEs may use more currency derivatives and more trading skills to reduce the foreign exchange exposures than the pure domestic companies. In Addae, Nyark-Baasi, and Tetteh (2014), they found that the foreign exchange rate movement will affect the quality of assets of Ghanaian banks.

In fact, the foreign exchange market in Taiwan is a small, regional market, so some foreign currencies transaction is not warm and the trading volume is small. The liquidities of the other currencies are lower than that of the international major currencies. As Harris (2003) has said that liquidity is the ability to trade large size quickly, at low cost, when you want to trade. Such that a lower liquidity will result to the company when buying foreign currency in order to circumvent the exposure of foreign exchange transactions, it cannot immediately trade at a predetermined price to the required foreign currency position. Hence, the transaction costs and carrying costs of the currencies will increase the cost of risk reduction and then increase the liquidity risk of assets. Here, according to Campbell, Medeiros, and Viceira (2010), regression models can be adopt to help the company to find out the effect on its performance causing by the currency's fluctuation. After finding the magnitudes of currency fluctuations which affect to the company's performance, then the framework of the Modern Portfolio Theory, proposed by Bailey, Ng, and Stulz, (1992) and Kim (2013), can be used to form their own foreign exchange risk management strategies and then to reduce the effect of foreign exchange exposures. This study applies the framework of Kim (2013) to investigate the effects of foreign exchange exposures on the performance of Taiwan hospitality industry and try to propose some hedging strategies and strengthen their corporate risk management. Therefore, as the shown in Jorion (1991), I will impose the changes of 
exchange rates of several currencies to study the effects of the fluctuations of exchange rates on the performance of Taiwan hotel companies.

\section{Methodologies}

\section{3-1. Modern Portfolio Theory, MPT}

Modern portfolio theory is proposed by Markowitz in 1952.In the paper, Probability Theory and Linear Algebra method are applied to investigate the correlation between the securities. It puts forward the possibility to diversify the main investment risks for this theory that regardless of the dispersion of individual investment targets the risks associated with some other securities can reduce the risk. In this way, individual company information becomes less important.

The theory is mainly to solve an investor's risk-reward problem and to form a rational combination of his/her own funds in order to maximize the proceeds. According to the Markowitz's framework, there is a certain special relationship between investment risk and return of a portfolio of financial assets. His assumptions are based on four conditions:

1. Assume the market is efficient, investors can learn more of the benefits and risks of financial market changes and their causes.

2. Suppose investors are risk averse and are willing to get a higher rate of return if they must bear a greater risk to get a higher expected return as compensation. Risk is the variability of yields as measured by standard deviation.

3. Investors' choices are based on the expected returns and standard deviations of selected financial assets portfolio. They select portfolios with higher yields or lower risk.

4. The incomes between various financial assets are correlated with the correlation coefficient between each financial asset, it is possible to choose the lowest risk of the portfolio.

An efficient portfolio should be subject to the following conditions: under certain risk (standard deviation).This combination of securities has the highest average reward; and in certain average reward, it has the lowest degree of risk (standard deviation).Therefore, the portfolio should be on the curve of efficient frontier.

According to Huang and Litzenberger (1988)and Elton, Gruber, Brown, and Goetzmann (2007), suppose an economy which there are $n$ risky assets with its return and standard deviation $R_{i}$ and $\sigma_{i}, i=1,2, \cdots, n$, respectively. Moreover, the covariance between any two assets is $\sigma_{i, j} \equiv \operatorname{Cov}\left(R_{i}, R_{j}\right), i \neq j=1,2, \cdots, n$. If we denote the portfolio weight on each assets in the portfolio to be $w_{i}, i=1,2, \cdots, n$, then the expected return of the portfolio is $\mu_{P} \equiv w^{\prime} \cdot R$, where $R \equiv\left(R_{1}, R_{2}, \cdots, R_{n}\right)^{\prime}$ and $w \equiv\left(w_{1}, w_{2}, \cdots, w_{n}\right)^{\prime} \circ$ And the variance of 
the portfolio is $\sigma_{P}^{2} \equiv w^{\prime} \cdot \Sigma \cdot w$, where $\Sigma \equiv \operatorname{Var}(R)=\left(\sigma_{i, j}\right)_{n \times n}$ the variance-covariance matrix is. Hence, in the framework of Markowitz (1952) and Kim (2013), we have to minimize the degree of risk of the portfolio under a pre-specified return, $\mu_{0}$, and budget constrain. Namely,

$$
\begin{aligned}
& \min _{w_{i}} \frac{\sigma_{P}^{2}}{2}=\frac{1}{2} w^{\prime} \cdot \Sigma \cdot w \\
& \text { s.t. }\left\{\begin{array}{l}
\mu_{P}=w^{\prime} \cdot R \geq \mu_{0} \\
J_{n}^{\prime} \cdot w=\sum_{i=1}^{n} w_{i}=1 \\
0 \leq w_{i} \leq 1, i=1,2, \cdots, n
\end{array}\right.
\end{aligned}
$$

where, $J_{n}=(1,1, \cdots, 1)^{\prime} \in \mathfrak{R}^{n}$. Using the Lagrange Multipliers method, the above problem can be transformed as follows:

$$
\min _{w_{i}, \lambda_{1}, \lambda_{2}} \ell\left(w, \lambda_{1}, \lambda_{2}\right)=\frac{1}{2} w^{\prime} \cdot \Sigma \cdot w+\lambda_{1} \cdot\left(\mu_{0}-w^{\prime} \cdot R\right)+\lambda_{2} \cdot\left(1-J_{n}^{\prime} \cdot w\right) .
$$

Hence, the F.O.C.is

$$
\left\{\begin{array}{l}
\frac{\partial \ell}{\partial w}=\Sigma \cdot w_{P}-\lambda_{1} \cdot R-\lambda_{2} \cdot J_{n}=0 \\
\frac{\partial \ell}{\partial \lambda_{1}}=\left(\mu_{0}-w_{P}^{\prime} \cdot R\right)=0 \\
\frac{\partial \ell}{\partial \lambda_{2}}=\left(1-J_{n}^{\prime} \cdot w_{P}\right)=0
\end{array} \quad \rightarrow w_{P}^{*}=\lambda_{1} \cdot \Sigma^{-1} \cdot R+\lambda_{2} \cdot \Sigma^{-1} \cdot J_{n}\right.
$$

And then we have,

$$
\left\{\begin{array} { c } 
{ \lambda _ { 1 } \cdot R ^ { \prime } \cdot \Sigma ^ { - 1 } \cdot R + \lambda _ { 2 } \cdot J _ { n } ^ { \prime } \cdot \Sigma ^ { - 1 } \cdot R = \mu _ { 0 } ^ { \prime } } \\
{ \lambda _ { 1 } \cdot J _ { n } ^ { \prime } \cdot \Sigma ^ { - 1 } \cdot R + \lambda _ { 2 } \cdot J _ { n } ^ { \prime } \cdot \Sigma ^ { - 1 } \cdot J _ { n } = 1 }
\end{array} \rightarrow \left\{\begin{array}{l}
\lambda_{1}=\frac{\mu_{0} \cdot C-B}{A C-B^{2}}=\frac{C}{D} \cdot \mu_{0}-\frac{B}{D} \\
\lambda_{2}=\frac{A-\mu_{0} \cdot B}{A C-B^{2}}=\frac{A}{D}-\frac{B}{D} \cdot \mu_{0}
\end{array},\right.\right.
$$

where, $A \equiv R^{\prime} \cdot \Sigma^{-1} \cdot R, \quad B \equiv J_{n}^{\prime} \cdot \Sigma^{-1} \cdot R=R^{\prime} \cdot \Sigma^{-1} \cdot J_{n}, C \equiv J_{n}^{\prime} \cdot \Sigma^{-1} \cdot J_{n}$, and $D \equiv A C-B^{2}$. Such that, the optimal wealth allocation portfolio is

$$
\begin{aligned}
w_{P}^{*} & =\lambda_{1} \cdot \Sigma^{-1} \cdot R+\lambda_{2} \cdot \Sigma^{-1} \cdot J_{n} \\
& =\left(\frac{C}{D} \cdot \mu_{0}-\frac{B}{D}\right) \cdot \Sigma^{-1} \cdot R+\left(\frac{A}{D}-\frac{B}{D} \cdot \mu_{0}\right) \cdot \Sigma^{-1} \cdot J_{n} .
\end{aligned}
$$

The properties of this portfolio are 


$$
\text { 1. } \begin{aligned}
\mu_{P} & =w_{P}^{*^{\prime}} \cdot R=\left(\frac{C}{D} \cdot \mu_{0}-\frac{B}{D}\right) \cdot R^{\prime} \cdot \Sigma^{-1} \cdot R+\left(\frac{A}{D}-\frac{B}{D} \cdot \mu_{0}\right) \cdot J_{n}^{\prime} \cdot \Sigma^{-1} \cdot R \\
& =\left(\frac{C}{D} \cdot \mu_{0}-\frac{B}{D}\right) \cdot A+\left(\frac{A}{D}-\frac{B}{D} \cdot \mu_{0}\right) \cdot B=\frac{A C-B^{2}}{D} \cdot \mu_{0}=\frac{D}{D} \mu_{0}=\mu_{0}
\end{aligned}
$$

2. $\sigma_{P}^{2}=w_{P}^{*} \cdot \Sigma \cdot w_{P}^{*}$

$$
\begin{aligned}
&= {\left[\left(\frac{C}{D} \mu_{0}-\frac{B}{D}\right) \cdot \Sigma^{-1} R+\left(\frac{A}{D}-\frac{B}{D} \mu_{0}\right) \cdot \Sigma^{-1} J_{n}\right]^{\prime} \cdot \Sigma } \\
& \cdot {\left[\left(\frac{C}{D} \mu_{0}-\frac{B}{D}\right) \cdot \Sigma^{-1} R+\left(\frac{A}{D}-\frac{B}{D} \mu_{0}\right) \cdot \Sigma^{-1} J_{n}\right] } \\
&=\left(\frac{C}{D} \cdot \mu_{0}-\frac{B}{D}\right)^{2} \cdot R^{\prime} \cdot \Sigma^{-1} \cdot R+\left(\frac{A}{D}-\frac{B}{D} \cdot \mu_{0}\right)^{2} \cdot J_{n}^{\prime} \cdot \Sigma^{-1} \cdot J_{n} \\
&+2\left(\frac{C}{D} \cdot \mu_{0}-\frac{B}{D}\right) \cdot\left(\frac{A}{D}-\frac{B}{D} \cdot \mu_{0}\right) \cdot R^{\prime} \cdot \Sigma^{-1} \cdot J_{n} \\
&= A \cdot\left(\frac{C}{D} \cdot \mu_{0}-\frac{B}{D}\right)^{2}+C \cdot\left(\frac{A}{D}-\frac{B}{D} \cdot \mu_{0}\right)^{2}+2 \cdot B \cdot\left(\frac{C}{D} \cdot \mu_{0}-\frac{B}{D}\right) \cdot\left(\frac{A}{D}-\frac{B}{D} \cdot \mu_{0}\right) \\
& \quad=\frac{1}{D}\left(C \cdot \mu_{0}^{2}-2 B \cdot \mu_{0}+A\right)=\frac{C}{D} \cdot\left(\mu_{0}-\frac{B}{C}\right)^{2}+\frac{1}{C}
\end{aligned}
$$

Such that, $\sigma_{P}^{2} \geq \frac{1}{C}$, and the equality holds when $\mu_{0}=\frac{B}{C}$.

Next, considering a riskless asset can be invested, and then the pre-described model will be rewritten as follows:

$$
\begin{aligned}
& \min _{w_{i}} \frac{\sigma_{P}^{2}}{2}=\frac{1}{2} w^{\prime} \cdot \Sigma \cdot w \quad(6) \\
& \text { s.t. } \quad \mu_{P}=\left(1-w^{\prime} \cdot J_{n}\right) \cdot r_{f}+w^{\prime} \cdot R \geq \mu_{0},
\end{aligned}
$$

where, $r_{f}$ is the return of the riskless asset. Again, by using the Lagrange Multipliers method, we have to solve the following problem:

$$
\min _{w_{i}, \lambda} \ell\left(w, \lambda_{1}, \lambda_{2}\right)=\frac{1}{2} w^{\prime} \cdot \Sigma \cdot w+\lambda \cdot\left[\mu_{0}-w^{\prime} \cdot R-\left(1-w^{\prime} \cdot J_{n}\right) \cdot r_{f}\right] .
$$

Thus, the F.O.C. is 


$$
\left\{\begin{array}{l}
\ell_{w}=\Sigma \cdot w-\lambda \cdot\left(R-J_{n} \cdot r_{f}\right)=0 \\
\ell_{\lambda}=\mu_{0}-w^{\prime} \cdot R-\left(1-w^{\prime} \cdot J_{n}\right) \cdot r_{f}=0
\end{array} \rightarrow w_{P}^{*}=\Sigma^{-1} \cdot\left(R-r_{f} \cdot J_{n}\right) \cdot \frac{\mu_{0}-r_{f}}{H}\right.
$$

where, $H \equiv\left(R-r_{f} \cdot J_{n}\right)^{\prime} \cdot \Sigma^{-1} \cdot\left(R-r_{f} \cdot J_{n}\right)=A-2 B \cdot r_{f}+C \cdot r_{f}^{2}$. The properties of this portfolio are:

$$
\text { 1. } \begin{aligned}
\mu_{P}= & w_{P}^{*^{\prime}} \cdot R+\left(1-w_{P}^{\prime} \cdot J_{n}\right) \cdot r_{f} \\
= & \left(R-r_{f} \cdot J_{n}\right)^{\prime} \cdot \Sigma^{-1} \frac{\mu_{0}-r_{f}}{H} \cdot R+\left(1-w_{P}^{\prime} \cdot J_{n}\right) \cdot r_{f} \\
= & \frac{\mu_{0}-r_{f}}{H} \cdot\left(R-r_{f} \cdot J_{n}\right)^{\prime} \cdot \Sigma^{-1} \cdot\left(R-r_{f} \cdot J_{n}\right) \\
& +\frac{r_{f} \cdot\left(\mu_{0}-r_{f}\right)}{H} \cdot\left(R-r_{f} \cdot J_{n}\right)^{\prime} \cdot \Sigma^{-1} \cdot J_{n}+\left(1-w_{P}^{*} \cdot J_{n}\right) \cdot r_{f} \cdot
\end{aligned}
$$

2. $\sigma_{P}^{2}=w_{P}^{*^{\prime}} \cdot \Sigma \cdot w_{P}^{*}$

$$
\begin{gathered}
=\left[\left(R-r_{f} \cdot J_{n}\right)^{\prime} \cdot \Sigma^{-1} \frac{\mu_{0}-r_{f}}{H}\right] \cdot \Sigma \cdot\left[\Sigma^{-1} \cdot\left(R-r_{f} \cdot J_{n}\right) \cdot \frac{\mu_{0}-r_{f}}{H}\right] \\
=\left(\frac{\mu_{0}-r_{f}}{H}\right)^{2} \cdot\left(R-r_{f} \cdot J_{n}\right)^{\prime} \cdot \Sigma^{-1} \cdot\left(R-r_{f} \cdot J_{n}\right) \\
=\left(\frac{\mu_{0}-r_{f}}{H}\right)^{2} \cdot\left[R^{\prime} \Sigma^{-1} R-2 r_{f} \cdot R^{\prime} \Sigma^{-} J_{n}+r_{f}^{2} \cdot J_{n}^{\prime} \Sigma^{-1} J_{n}\right] \\
=\frac{\left(\mu_{0}-r_{f}\right)^{2}}{H} .
\end{gathered}
$$

Hence, its standard deviation $\sigma_{P}=\frac{\left|\mu_{0}-r_{f}\right|}{\sqrt{H}}$, that is,

$$
\mu_{0}=r_{f} \pm \sqrt{H} \cdot \sigma_{P}(10)
$$

\subsection{Autoregression Integrated Moving Average Models, ARIMA(p,d,q)}

In Witt and Witt (1992, 1995), they use many econometric models to investigate the topics of tourism industries. Empirically, they suggested that the autoregression and moving average models can be implemented to forecast the performance of tourism industries. This study will focus on the effects of the fluctuations of foreign exchange on the performance of hotel industry. 
According to Bodie, Kane and Marcus (2002) and Muriithi, Muturi, and Waweru (2016), we can use the ROA or ROE, reported in the annual financial statements, to be the measures of the corporate's performance. There are at least two reasons for applying ROA/ROE to proxy the firm's performance. First, since ROA is the return of corporate's total assets, which is defined by the product of profit margin and total asset turnover, so it tells us how effectively a firm uses its assets to generate profits. Therefore, a well-performed firm will have a higher ROA. Second, the definition of ROE is the net profit over the average equity, so that by the DuPont equation, we have

$$
R O E=\text { Net Profit Margin } \times \text { Asset Turnover } \times \frac{\text { Asset }}{\text { Equity Ratio }} .
$$

As a result, it tells us how efficiently a company is operated. It also provides insights into the firm's use of assets via turnover.That is, a well-performed firm also has a higher ROE. As a result, in our study, we will apply these two measures to be the proxies of the firm's performance and investigate the magnitude of the effects of foreign exchange rate's fluctuations. Hence, by the multi-factor model in Jorion (1991) and Bartram (2008), the autoregression moving average model is given as follows:

$$
\begin{gathered}
\text { Performance }_{i, t}=\alpha_{i}+\beta_{i, m} \cdot R M R F_{t}+\sum_{k=1}^{p} \phi_{i, k} \cdot \text { Performance }_{i, t-k} \\
+\sum_{j=1}^{n} \gamma_{i, j} \cdot \Delta F X_{j, t}+\delta_{i} \cdot \text { Size }_{i, t}+\sum_{s=0}^{q} \theta_{s} \cdot a_{i, t-s}, \\
t=\max (p, q)+1, \max (p, q)+2, \cdots, T_{i}, i=1,2, \cdots, N .
\end{gathered}
$$

Here, Performance ${ }_{i, t}$ represents the $i$-th firm's performance in the $t$-th quarter, and Performane $_{i, t-k}$ is its $k$-th lagged variable. In Sharpe (1964), he defined that $R M R F{ }_{t}$ is the market portfolio's excess return in the $t$-th quarter, i.e., $R M R F_{t} \equiv R m_{t}-r_{f}$, and $R m_{t}$ is the market portfolio's return and $r_{f}$ is the rate of return of riskless asset.

Furthermore, as indicated in Smithson andSimkins (2005), although themanagement of interest rate and foreign exchange rate risksdoes indeed add value, the effect is larger than would beexpected.And by the definition ofMuller and Verschoor (2006), let $\Delta F X_{j, t}$ be the percentage change of exchange rate of the $j$-th currency in the $t$-th quarter, that is

$$
\Delta F X_{j, t} \equiv \frac{E_{j, t}-E_{j, t-1}}{E_{j, t-1}} \times 100,
$$

where $E_{j, t}$ is the closed price in the end of the quarter in terms of direct quotation. Moreover, 
in Fama and French $(1993,1995)$, they formed six portfolios of the stocks listed on NYSE, AMX, and NASDAQ Stock Market by the firm's size and found that firm's size and BE/ME proxy for sensitivity to risk factors that capture strong common variation in stock returns and will help to explain the average returns and then firm's profitability. Such that, let Size $e_{i, t}$ denote the size of the $i$-th firm in the $t$-th quarter which is defined as $\operatorname{Size}_{i, t} \equiv \ln \left(\operatorname{Cap}_{i, t}\right)$, and $\operatorname{Cap}_{i, t}$ is the capitalization of the firm in the $t$-th quarter. $a_{i, t}$ is the white noises.

\section{Data}

This paper selected twelve hotel companies listed on Taiwan Stock Exchange (TWSE), and downloaded their quarterly ROA, ROE and capitalization from Taiwan Economic Journal (TEJ). They are Hotel Holiday Garden(2702), The Ambassador Hotel Ltd.(2704), The Leofoo Development Co., Ltd.(2705), First Hotel Company Ltd.(2706), Formosa International Hotels Corporation(2707), Farglory Hotel Co., Ltd.(2712), Pleasant Hotels International Inc.(2718), Chateau International Development Co., Ltd.(2722), FX Hotels Group Inc.(2724-F), Janfusun Fancyworld Corp.(5701), The Landis Taipei Hotel Co., Ltd.(5703), and Hotel Royal Chihpen(5704). Period is from 2000Q1 to 2015Q3 and sum to 489 firm-quarters. Table 1 shows the descriptive statistics of the firm's ROA and ROE, respectively.

Table 1(A). Descriptive statistics of ROA.

\begin{tabular}{lcrcrrr}
\hline ROA (\%) & Obs. & Mean & Std. dev. & Max & Min & Median \\
\hline 2702HG & 63 & 0.661 & 0.820 & 2.94 & -1.43 & 0.740 \\
2704AMBH & 63 & 0.641 & 0.565 & 1.47 & -1.29 & 0.740 \\
2705Leofoo & 32 & -0.136 & 1.298 & 5.40 & -5.03 & -0.225 \\
2706First Hotel & 32 & 1.398 & 1.105 & 7.28 & 0.54 & 1.160 \\
2707GFRT & 63 & 4.392 & 1.195 & 7.55 & 1.27 & 4.360 \\
2712FGH & 11 & 1.383 & 1.244 & 3.68 & -0.12 & 0.870 \\
2718PH & 25 & 0.944 & 0.873 & 2.40 & -1.20 & 0.840 \\
2722Chateau & 21 & 2.732 & 2.632 & 8.38 & -0.60 & 2.380 \\
2724FX Hotels & 21 & 1.179 & 1.770 & 5.74 & -2.45 & 1.550 \\
5701JFS & 32 & -1.462 & 1.341 & 1.73 & -5.76 & -1.470 \\
5703Landis Taipei & 63 & 0.419 & 1.724 & 3.20 & -8.97 & 0.740 \\
5704Chihpen Royal & 63 & 1.040 & 1.381 & 3.62 & -3.49 & 1.210 \\
\hline
\end{tabular}




\section{Macrothink}

Table 1(B). Descriptive statistics of ROE

\begin{tabular}{lcrcrrr}
\hline ROE (\%) & Obs. & Mean & Std. dev. & Max & Min & Median \\
\hline 2702 HG & 63 & 0.804 & 1.276 & 3.77 & -2.97 & 0.940 \\
2704AMBH & 63 & 0.704 & 0.956 & 2.18 & -2.96 & 0.880 \\
2705Leofoo & 32 & -0.415 & 2.565 & 11.04 & -9.90 & -0.695 \\
2706First Hotel & 32 & 1.668 & 1.339 & 8.71 & 0.67 & 1.390 \\
2707GFRT & 63 & 6.645 & 2.205 & 11.13 & 1.50 & 6.700 \\
2712FGH & 11 & 1.794 & 1.782 & 4.81 & -0.44 & 1.100 \\
2718PH & 25 & 1.220 & 1.109 & 2.99 & -1.62 & 1.160 \\
2722Chateau & 21 & 3.313 & 3.335 & 11.24 & -0.68 & 3.060 \\
2724FX Hotels & 21 & 1.418 & 3.958 & 6.96 & -8.83 & 2.210 \\
5701JFS & 32 & -3.217 & 2.462 & 2.47 & -11.24 & -3.300 \\
5703Landis Taipei & 63 & 0.612 & 2.338 & 4.48 & -11.76 & 1.040 \\
5704Chihpen Royal & 63 & 1.192 & 1.581 & 4.19 & -3.83 & 1.300 \\
\hline
\end{tabular}

Source: Taiwan Economic Journal (TEJ).

In Table 1, we may find that the Formosa International Hotels Corporation(2707) has the highest ROA and ROE, however, Janfusun Fancyworld Corp.(5701) has the lowest ROA and ROE. And except of Janfusun Fancyworld Corp. and the Leofoo Development Co., Ltd. (2705), the others are well-performed since they all have a positive average ROA or ROE. Moreover, the Ambassador Hotel Ltd. (2704) has the lowest volatility of ROA and ROE. On the other hand, Chateau International Development Co., Ltd. (2722) and the FX Hotels Group Inc. (2724-F)have the highest volatility of ROA and ROE, respectively. It may result from the shortest listing data of these two companies.

Next, the foreign exchange rates were collected from 2000 to 2015 through the website ${ }^{2}$ of the Central Bank of Taiwan. The equation (13) calculates the quarterly and monthly percentage change of exchange rates for the currencies against to the NT dollars (NTD). Table 2 shows the descriptive statistics of the monthly change of foreign exchange rates.

${ }^{2}$ http://www.cbc.gov.tw/content.asp?mp=1\&CuItem=36599. 
Table 2. Descriptive statistics of the monthly change of exchange rates

\begin{tabular}{lrrrrrr}
\hline $\begin{array}{l}\text { Monthly } \\
\text { Change (\%) }\end{array}$ & Mean & Std. dev. & \multicolumn{1}{l}{ Max } & \multicolumn{1}{l}{ Min } & Median & \multicolumn{1}{c}{ CV } \\
\hline USD & 0.0280 & 1.1865 & 3.3313 & -3.5798 & 0.0232 & 42.3750 \\
JPY & -0.0353 & 2.3233 & 8.8309 & -6.0498 & -0.2280 & -65.8159 \\
GBP & 0.0135 & 1.9269 & 5.7608 & -8.0517 & 0.0901 & 142.7333 \\
CNY & 0.1664 & 1.1449 & 3.0715 & -3.4686 & 0.1749 & 6.8804 \\
EUR & 0.1016 & 2.2251 & 7.1016 & -5.2660 & 0.2209 & 21.9006 \\
HKD & 0.0294 & 1.1841 & 3.3179 & -3.5798 & 0.0205 & 40.2755 \\
KRW & 0.0170 & 1.8737 & 6.7195 & -12.3726 & 0.2496 & 110.2176 \\
CAD & 0.0940 & 1.8282 & 5.0170 & -8.6264 & 0.0351 & 19.4489 \\
SGD & 0.1155 & 0.9621 & 3.0253 & -3.4506 & 0.1384 & 8.3299 \\
AUD & 0.1074 & 2.6040 & 6.9746 & -13.5568 & 0.2725 & 24.2458 \\
IDR & -0.3005 & 3.1096 & 20.7023 & -13.5534 & -0.2083 & -10.3481 \\
THB & 0.0602 & 1.2869 & 3.6022 & -4.5300 & 0.0806 & 21.3771 \\
MYR & -0.0366 & 1.2266 & 3.0689 & -4.0603 & -0.0825 & -33.5137 \\
PHP & -0.0412 & 1.5530 & 4.3555 & -4.5580 & -0.1633 & -37.6942 \\
\hline
\end{tabular}

Source: Central Bank of Taiwan.

In Table 2 , the lowest percentage change $(0.96 \%)$ of the exchange rate is the Singapore dollar against to NT dollar, and the highest percentage change $(3.11 \%)$ of the exchange rate is the Indonesian rupiah against to NT dollar. Indonesian rupiah has a maximum appreciation (20.70\%) and minimum depreciation (13.56\%) against to NT dollar. Moreover, the coefficient of variation is also reported in Table 2.The standard deviation of data describes the dispersion of the data away from the mean. In contrast, the coefficient of variation is the multiple of the standard deviation to the mean, i.e. $C V \equiv \frac{\sigma}{\mu}$. For comparison between data sets with different units or widely different means, this paper uses the coefficient of variation instead of the standard deviation. Scheel (1978) proposed that the coefficient of variation can also be a measure of relative risk in the elementary risk and insurance. An asset with lower value of coefficient of variation means either a lower-risk asset among that of the same return or a higher-return asset among that of same level of risk. As shown in Table 2, China yuan (CNY) and Singapore dollar (SGD) have lower coefficient of variation, 6.8804and 8.3299, respectively, and Great British pound and Korean won have higher coefficient of variation. Both Great British pound and Korean won are either high-risk or low-return.

\section{Empirical Results and Analysis}

First, we have to test whether the series of performance is stationary or not. That is, we should test the null hypothesis that it has a unit root. In Tsay (2005), he indicated that the fundamental time series analysis is stationarity. A time series $y_{t}$ is said to be strictly 
stationary if the joint distribution of $\left(y_{t_{1}}, y_{t_{2}}, \cdots, y_{t_{k}}\right)^{\prime}$ is identical to that of $\left(y_{t_{1}+s}, y_{t_{2}+s}, \cdots, y_{t_{k}+s}\right)^{\prime}$ for all $k$, where $s$ is an arbitrary positive integer. In other words, strict stationarity requires that the joint distribution of $\left(y_{t_{1}}, y_{t_{2}}, \cdots, y_{t_{k}}\right)^{\prime}$ is invariant under time shift. And a time series $y_{t}$ is weakly stationary if both the mean of $y_{t}$ and $\operatorname{Cov}\left(y_{t}, y_{t-s}\right)$ are time-invariant, where sis an arbitrary integer. In the Table 3, we show the Augmented Dicky-Fuller test results. As shown in Table 3, we can find that almost all the ROA/ROE series are non-stationary except the Ambassador's ROA/ROE.

On the other hand, according to Hurvich and Tsai (1989), there will be biased estimates resulting from a non-stationary series. Such that, applying Wei (2006), we take the first-ordered difference on the series, i.e.,

$$
D_{1} R O A_{t} \equiv R O A_{t}-R_{t-1} \text { and } D_{1} R O E_{t} \equiv R O E_{t}-R O E_{t-1} .
$$

And then, we test the unit-root-test again to verify its stationarity. The Augmented Dicky-Fuller test results are also shown in Table 3. After differencing the series, all of them are stationary. 


\section{Macrothink}

Table 3. The stationarity test results of company's performances

\begin{tabular}{|c|c|c|c|c|c|}
\hline SEC & Series & Obs. & $\begin{array}{r}\text { ADF test } \\
\text { statistic }\end{array}$ & $p$-value & Stationarity \\
\hline \multirow[t]{2}{*}{2702} & $R O A$ & 56 & -1.539 & 0.5140 & Non-stationary \\
\hline & $\triangle R O A$ & 61 & -14.607 & 0.0000 & Stationary \\
\hline 2704 & $R O A$ & 56 & -2.884 & 0.0472 & Stationary \\
\hline \multirow[t]{2}{*}{2705} & $R O A$ & 56 & -2.158 & 0.2217 & Non-stationary \\
\hline & $\triangle R O A$ & 61 & -12.592 & 0.0000 & Stationary \\
\hline \multirow[t]{2}{*}{2706} & $R O A$ & 56 & -2.312 & 0.1683 & Non-stationary \\
\hline & $\triangle R O A$ & 61 & -17.520 & 0.0000 & Stationary \\
\hline \multirow[t]{2}{*}{2707} & $R O A$ & 56 & -2.640 & 0.0849 & Non-stationary \\
\hline & $\triangle R O A$ & 61 & -12.541 & 0.0000 & Stationary \\
\hline 2712 & $R O A$ & 9 & -3.466 & 0.0089 & Stationary \\
\hline \multirow[t]{2}{*}{2718} & $R O A$ & 18 & -1.651 & 0.4567 & Non-stationary \\
\hline & $\triangle R O A$ & 23 & -9.001 & 0.0000 & Stationary \\
\hline \multirow[t]{2}{*}{2722} & $R O A$ & 14 & -1.810 & 0.3755 & Non-stationary \\
\hline & $\triangle R O A$ & 19 & -5.904 & 0.0000 & Stationary \\
\hline \multirow[t]{2}{*}{2724} & $R O A$ & 14 & 0.025 & 0.9606 & Non-stationary \\
\hline & $\triangle R O A$ & 19 & -5.816 & 0.0000 & Stationary \\
\hline \multirow[t]{2}{*}{5701} & $R O A$ & 56 & -1.476 & 0.5452 & Non-stationary \\
\hline & $\triangle R O A$ & 61 & -11.789 & 0.0000 & Stationary \\
\hline \multirow[t]{2}{*}{5703} & $R O A$ & 56 & -1.977 & 0.2967 & Non-stationary \\
\hline & $\triangle R O A$ & 61 & -10.758 & 0.0000 & Stationary \\
\hline \multirow[t]{2}{*}{5704} & $R O A$ & 56 & -1.421 & 0.5722 & Non-stationary \\
\hline & $\triangle R O A$ & 61 & -17.149 & 0.0000 & Stationary \\
\hline
\end{tabular}


Table 3(B). The stationarity test results of company's ROE

\begin{tabular}{|c|c|c|c|c|c|}
\hline SEC & Series & Obs. & $\begin{array}{l}\text { ADF test } \\
\text { statistic }\end{array}$ & $p$-value & Stationarity \\
\hline \multirow[t]{2}{*}{2702} & $R O E$ & 56 & -1.604 & 0.4814 & Non-stationary \\
\hline & $\triangle R O E$ & 61 & -15.323 & 0.0000 & Stationary \\
\hline 2704 & $R O E$ & 56 & -2.993 & 0.0356 & Stationary \\
\hline \multirow[t]{2}{*}{2705} & $R O E$ & 25 & -2.061 & 0.2604 & Non-stationary \\
\hline & $\triangle R O E$ & 30 & -8.296 & 0.0000 & Stationary \\
\hline \multirow[t]{2}{*}{2706} & $R O E$ & 25 & -2.441 & 0.1306 & Non-stationary \\
\hline & $\triangle R O E$ & 30 & -13.890 & 0.0000 & Stationary \\
\hline \multirow[t]{2}{*}{2707} & $R O E$ & 56 & -1.808 & 0.3764 & Non-stationary \\
\hline & $\triangle R O E$ & 61 & -11.738 & 0.0000 & Stationary \\
\hline 2712 & $R O E$ & 9 & -3.501 & 0.0080 & Stationary \\
\hline \multirow[t]{2}{*}{2718} & $R O E$ & 18 & -1.689 & 0.4365 & Non-stationary \\
\hline & $\triangle R O E$ & 23 & -8.826 & 0.0000 & Stationary \\
\hline \multirow[t]{2}{*}{2722} & $R O E$ & 14 & -2.132 & 0.2320 & Non-stationary \\
\hline & $\triangle R O E$ & 19 & -6.034 & 0.0000 & Stationary \\
\hline \multirow[t]{2}{*}{2724} & $R O E$ & 14 & 0.394 & 0.9813 & Non-stationary \\
\hline & $\triangle R O E$ & 19 & -7.304 & 0.0000 & Stationary \\
\hline \multirow[t]{2}{*}{5701} & $R O E$ & 25 & -2.505 & 0.1143 & Non-stationary \\
\hline & $\triangle R O E$ & 30 & -8.123 & 0.0000 & Stationary \\
\hline \multirow[t]{2}{*}{5703} & $R O E$ & 56 & -1.942 & 0.3124 & Non-stationary \\
\hline & $\triangle R O E$ & 61 & -10.652 & 0.0000 & Stationary \\
\hline \multirow[t]{2}{*}{5704} & $R O E$ & 56 & -1.332 & 0.6146 & Non-stationary \\
\hline & $\triangle R O E$ & 61 & -17.278 & 0.000 & Stationary \\
\hline
\end{tabular}

Next, Patro, Wald, and Wu (2002) found the significant currency risk exposures in country equity index returns by using the GARCH model. And, Polodoo, Seetanah, and Sannassee (2016) discussed the nexus between exchange rate volatility and manufacturing trade. They found that exchange rate volatility has an adverse effect on the real manufacturing trade of the Africa countries. As shown in Kelilume (2016), he applied the dynamic panel regression approach to investigate the effects of exchange rate volatility on firm performance by examining 20 companies listing in Nigerian Stock Exchange. It revealed that exchange rate volatility has significant negative impacts on the ROAs, ATRs. Here, that the effects of the fluctuations of exchange rates on the firm's performance is the main purpose of this study. Therefore, like the work in Kim (2012), the following autoregression moving average (ARIMA) model:

$$
D_{1} \text { Performance }_{i, t}=\alpha_{i}+\beta_{i, m} \cdot R M R F_{t}+\sum_{k=1}^{p} \phi_{i, k} \cdot D_{1} \text { Performance }_{i, t-k}
$$




$$
\begin{gathered}
+\sum_{j=1}^{n} \gamma_{i, j} \cdot \Delta F X_{j, t}+\delta_{i} \cdot \text { Size }_{i, t}+\sum_{s=0}^{q} \theta_{s} \cdot a_{i, t-s},(15) \\
t=\max (p, q)+1, \max (p, q)+2, \cdots, T_{i}, \quad i=1,2, \cdots, N .
\end{gathered}
$$

Where, $D_{1}$ Performance $_{i, t}$ represents the first-ordered difference of the $i$-th firm's performance in the $t$-th quarter, and $D_{1}$ Performanc $e_{i, t-k}$ is its $k$-th lagged variable. Use the STATA13 to find the regression results and shown in the Table 4. Model I regresses $D_{1} R O A$ on all exchange fluctuations, lagged variables and the control variables. Model II regresses $D_{1} R O A$ on all variables but selected by eliminating higher $p$-value explanatory variables.

Table 4. Regression on ROA

The regression model is given as follows:

$$
D_{1} R O A_{, t}=\alpha_{i}+\beta_{i, m} \cdot R M R F_{t}+\sum_{k=1}^{p} \phi_{i, k} \cdot D_{1} R O A_{, t-k}+\sum_{j=1}^{n} \gamma_{i, j} \cdot \Delta F X_{j, t}+\delta_{i} \cdot \text { Size }_{i, t}+a_{i, t} \cdot
$$

Model I regresses $D_{1} R O A_{, t,} \equiv R O A_{\cdot, t}-R O A_{, t,-1}$ on all exchange fluctuations, lagged variables and the control variables. Model II regresses $D_{1} R O A$ on all variables but selected by eliminating higher $p$-value explanatory variables. The values in the parentheses are standard

\begin{tabular}{|c|c|c|c|c|c|c|}
\hline \multirow{2}{*}{\begin{tabular}{|l} 
Company \\
Variables
\end{tabular}} & \multicolumn{2}{|c|}{$\begin{array}{l}\text { Hotel Holiday } \\
\text { Garden (2702) }\end{array}$} & \multicolumn{2}{|c|}{$\begin{array}{c}\text { The Leofoo } \\
\text { Development Co., Ltd. } \\
(2705)\end{array}$} & \multicolumn{2}{|c|}{$\begin{array}{c}\text { Formosa International } \\
\text { Hotels Corporation }(2707)\end{array}$} \\
\hline & Model I & Model II & Model I & Model II & Model I & Model II \\
\hline Const. & $\begin{array}{l}10.31 \\
(7.59)\end{array}$ & $\begin{array}{r}0.10 \\
(0.09)\end{array}$ & $\begin{array}{l}106.98 \\
(81.09)\end{array}$ & $\begin{array}{l}101.70 * * \\
(47.14)\end{array}$ & $\begin{array}{c}23.71 \\
(16.21)\end{array}$ & $\begin{array}{l}-0.06 \\
(0.14)\end{array}$ \\
\hline RMRF & $\begin{array}{c}0.01 \\
(0.01)\end{array}$ & & $\begin{array}{l}-0.05 \\
(0.07)\end{array}$ & & $\begin{array}{l}-0.01 \\
(0.02)\end{array}$ & \\
\hline USD & $\begin{array}{c}0.14 \\
(0.14)\end{array}$ & & $\begin{array}{r}0.15 \\
(0.33)\end{array}$ & & $\begin{array}{r}0.10 \\
(0.20)\end{array}$ & \\
\hline JPY & $\begin{array}{c}0.03 \\
(0.03)\end{array}$ & & $\begin{array}{l}-0.01 \\
(0.09)\end{array}$ & & $\begin{array}{l}-0.05 \\
(0.05)\end{array}$ & \\
\hline
\end{tabular}
error of the estimates. And $*, * *$ and $* * *$ stand for $10 \%, 5 \%$ and $1 \%$ level of significance, respectively. 


\begin{tabular}{|c|c|c|c|c|c|c|}
\hline \multirow[b]{2}{*}{ CNY } & $\begin{array}{l}\text { acroi } \\
\text { stitu }\end{array}$ & $\ln k$ & & \multicolumn{3}{|c|}{$\begin{array}{r}\text { Asian Journal of Finance \& Accounting } \\
\text { ISSN 1946-052X } \\
\text { 2017, Vol. 9, No. } 1\end{array}$} \\
\hline & $\begin{array}{l}-0.09 \\
(0.14)\end{array}$ & & $\begin{array}{l}-0.38 \\
(0.36)\end{array}$ & & $\begin{array}{l}-0.21 \\
(0.21)\end{array}$ & \\
\hline EUR & $\begin{array}{l}-0.05 \\
(0.05)\end{array}$ & & $\begin{array}{r}0.09 \\
(0.13)\end{array}$ & & $\begin{array}{l}-0.00 \\
(0.08)\end{array}$ & \\
\hline KRW & $\begin{array}{c}0.02 \\
(0.04)\end{array}$ & & $\begin{array}{c}0.28 * \\
(0.14)\end{array}$ & $\begin{array}{l}0.20 * * \\
(0.08)\end{array}$ & $\begin{array}{r}0.04 \\
(0.07)\end{array}$ & \\
\hline GBP & $\begin{array}{c}0.03 \\
(0.05)\end{array}$ & & $\begin{array}{l}-0.12 \\
(0.17)\end{array}$ & & $\begin{array}{l}-0.03 \\
(0.08)\end{array}$ & \\
\hline SGD & $\begin{array}{r}0.05 \\
(0.14)\end{array}$ & & $\begin{array}{c}0.51 \\
(0.62)\end{array}$ & $\begin{array}{l}0.41 * \\
(0.21)\end{array}$ & $\begin{array}{r}0.06 \\
(0.21)\end{array}$ & \\
\hline AUD & $\begin{array}{l}-0.04 \\
(0.04)\end{array}$ & $\begin{array}{l}-0.04 * \\
(0.02)\end{array}$ & $\begin{array}{l}-0.21 \\
(0.19)\end{array}$ & $\begin{array}{l}-0.20 * * \\
(0.07)\end{array}$ & $\begin{array}{r}0.06 \\
(0.06)\end{array}$ & $\begin{array}{l}0.09 * * * \\
(0.03)\end{array}$ \\
\hline IDR & $\begin{array}{r}0.03 \\
(0.03)\end{array}$ & $\begin{array}{l}0.05^{* *} \\
(0.02)\end{array}$ & $\begin{array}{c}0.01 \\
(0.13)\end{array}$ & & $\begin{array}{l}-0.09 * \\
(0.05)\end{array}$ & $\begin{array}{l}-0.07 * * \\
(0.03)\end{array}$ \\
\hline THB & $\begin{array}{c}0.05 \\
(0.06)\end{array}$ & & $\begin{array}{c}0.22 \\
(0.20)\end{array}$ & & $\begin{array}{l}-0.00 \\
(010)\end{array}$ & \\
\hline MYR & $\begin{array}{l}-0.03 \\
(0.07)\end{array}$ & & $\begin{array}{l}-0.17 \\
(0.21)\end{array}$ & & $\begin{array}{l}-0.01 \\
(0.11)\end{array}$ & \\
\hline PHP & $\begin{array}{l}-0.04 \\
(0.06)\end{array}$ & & $\begin{array}{l}-0.07 \\
(0.18)\end{array}$ & & $\begin{array}{r}0.09 \\
(0.09)\end{array}$ & \\
\hline Lag1 & $\begin{array}{l}-0.83 * * * \\
(0.18)\end{array}$ & $\begin{array}{l}0.67 * * * \\
(0.13)\end{array}$ & $\begin{array}{l}-0.91 * * \\
(0.33)\end{array}$ & $\begin{array}{l}-0.76^{* * * *} \\
(0.18)\end{array}$ & $\begin{array}{l}-0.69 * * * \\
(0.15)\end{array}$ & $\begin{array}{l}-0.57 * * * \\
(0.12)\end{array}$ \\
\hline Lag2 & $\begin{array}{l}-0.63 * * * \\
(0.20)\end{array}$ & $\begin{array}{l}-0.49 * * * \\
(0.14)\end{array}$ & $\begin{array}{l}-0.34 \\
(0.34)\end{array}$ & $\begin{array}{l}-0.35^{* *} \\
(0.17)\end{array}$ & $\begin{array}{l}-0.80 * * * \\
(0.16)\end{array}$ & $\begin{array}{l}-0.67 * * * \\
(0.12)\end{array}$ \\
\hline Lag 3 & $\begin{array}{l}-0.45^{* *} \\
(0.19)\end{array}$ & $\begin{array}{l}-0.45^{* * *} \\
(0.11)\end{array}$ & $\begin{array}{l}0.01 \\
(0.33)\end{array}$ & & $\begin{array}{l}-0.51 * * * \\
(0.15)\end{array}$ & $\begin{array}{l}-0.35^{* * *} \\
(0.11)\end{array}$ \\
\hline Lag4 & $\begin{array}{c}0.01 \\
(0.15)\end{array}$ & & $\begin{array}{l}-0.04 \\
(0.25)\end{array}$ & & $\begin{array}{l}-0.13 \\
(0.15)\end{array}$ & \\
\hline SIZE & $\begin{array}{l}-0.53 \\
(0.36)\end{array}$ & & $\begin{array}{l}-4.70 \\
(3.57)\end{array}$ & $\begin{array}{l}-4.48 * * \\
(2.08)\end{array}$ & $\begin{array}{l}-1.06 \\
(0.73)\end{array}$ & \\
\hline $\operatorname{Adj.} \mathbf{R}^{2}$ & 0.46 & 0.51 & 0.03 & 0.32 & 0.38 & 0.44 \\
\hline Obs. & 59 & 58 & 32 & 32 & 58 & 58 \\
\hline
\end{tabular}


Table 4. Regression on ROA (Continued)

\begin{tabular}{|c|c|c|c|c|c|c|}
\hline \multirow{2}{*}{$\begin{array}{l}\text { Company } \\
\text { Variables }\end{array}$} & \multicolumn{2}{|c|}{$\begin{array}{c}\text { First Hotel Company } \\
\text { Ltd. (2706) }\end{array}$} & \multicolumn{2}{|c|}{$\begin{array}{l}\text { Pleasant Hotels } \\
\text { International } \\
\text { Inc.(2718) } \\
\end{array}$} & \multicolumn{2}{|c|}{$\begin{array}{c}\text { Chateau International } \\
\text { Development Co., Ltd. } \\
(2722)\end{array}$} \\
\hline & Model I & Model II & Model I & Model II & Model I & Model II \\
\hline Const. & $\begin{array}{l}-8.17 \\
(15.86)\end{array}$ & $-14.17^{*}$ & $\begin{array}{l}37.34 \\
(58.01)\end{array}$ & $\begin{array}{l}0.71 * * * \\
(0.12)\end{array}$ & $\begin{array}{l}-1957 * * \\
(542.5)\end{array}$ & $\begin{array}{r}0.29 \\
(0.85)\end{array}$ \\
\hline RMRF & $\begin{array}{c}0.01 \\
(0.01)\end{array}$ & & $\begin{array}{l}-0.12 \\
(0.10)\end{array}$ & $\begin{array}{l}-0.06^{* *} \\
(0.03)\end{array}$ & $\begin{array}{l}3.33 * * * \\
(0.79)\end{array}$ & \\
\hline USD & $\begin{array}{r}0.06 \\
(0.05)\end{array}$ & & $\begin{array}{r}1.54 \\
(1.07)\end{array}$ & $\begin{array}{l}0.66 * * * \\
(0.15)\end{array}$ & $\begin{array}{l}-13.15^{* *} \\
(4.20)\end{array}$ & \\
\hline JPY & $\begin{array}{c}0.01 \\
(0.01)\end{array}$ & & $\begin{array}{l}-0.30 \\
(0.12)\end{array}$ & & $\begin{array}{l}3.14 * * * \\
(0.76)\end{array}$ & \\
\hline CNY & $\begin{array}{l}-0.05 \\
(0.06)\end{array}$ & & $\begin{array}{l}-1.36 \\
(0.72)\end{array}$ & $\begin{array}{l}-0.78 * * * \\
(0.14)\end{array}$ & $\begin{array}{l}12.03 * * \\
(3.78)\end{array}$ & \\
\hline EUR & $\begin{array}{r}0.00 \\
(0.02)\end{array}$ & & $\begin{array}{l}-0.29 \\
(0.20)\end{array}$ & $\begin{array}{l}-0.16^{* * *} \\
(0.04)\end{array}$ & $\begin{array}{l}7.60 * * \\
(1.96)\end{array}$ & \\
\hline KRW & $\begin{array}{l}-0.00 \\
(0.02)\end{array}$ & & $\begin{array}{r}0.23 \\
(0.23)\end{array}$ & & $\begin{array}{l}-5.31 * * \\
(1.49)\end{array}$ & \\
\hline GBP & $\begin{array}{l}-0.02 \\
(0.03)\end{array}$ & & $\begin{array}{l}-0.26 \\
(0.38)\end{array}$ & & $\begin{array}{l}-6.44 * * * \\
(1.50)\end{array}$ & \\
\hline SGD & $\begin{array}{l}-0.05 \\
(0.07)\end{array}$ & & $\begin{array}{l}-0.66 \\
(0.43)\end{array}$ & $\begin{array}{l}-0.66^{* *} \\
(0.11)\end{array}$ & $\begin{array}{c}1.41 \\
(0.74)\end{array}$ & $\begin{array}{l}1.89 * * \\
(0.85)\end{array}$ \\
\hline AUD & $\begin{array}{l}-0.01 \\
(0.02)\end{array}$ & & $\begin{array}{c}0.21 \\
(0.13)\end{array}$ & $\begin{array}{l}0.13^{* *} \\
(0.05)\end{array}$ & $\begin{array}{l}-4.36 * * * \\
(0.91)\end{array}$ & $\begin{array}{l}-0.58^{*} \\
(0.29)\end{array}$ \\
\hline IDR & $\begin{array}{c}0.03 \\
(0.02)\end{array}$ & & $\begin{array}{c}0.20 \\
(0.08)\end{array}$ & $\begin{array}{l}0.22^{* * *} \\
(0.03)\end{array}$ & $\begin{array}{c}0.59^{*} \\
(0.24)\end{array}$ & \\
\hline ТНВ & $\begin{array}{r}0.00 \\
(0.04)\end{array}$ & & $\begin{array}{c}0.58 \\
(0.32)\end{array}$ & $\begin{array}{l}0.55^{* * *} \\
(0.12)\end{array}$ & $\begin{array}{l}-13.42^{* * * *} \\
(3.22)\end{array}$ & \\
\hline MYR & $\begin{array}{l}-0.02 \\
(0.03)\end{array}$ & & $\begin{array}{l}-0.06 \\
(0.16)\end{array}$ & & $\begin{array}{l}3.75^{* *} \\
(0.96)\end{array}$ & \\
\hline PHP & $\begin{array}{l}-0.04 \\
(0.03)\end{array}$ & $\begin{array}{l}-0.04 * * * \\
(0.01)\end{array}$ & $\begin{array}{l}-1.06 \\
(0.43)\end{array}$ & & $\begin{array}{l}18.45^{* *} \\
(4.82)\end{array}$ & \\
\hline Lag1 & $\begin{array}{l}-1.05^{* * *} \\
(0.22)\end{array}$ & $\begin{array}{l}-1.21 * * * \\
(0.14)\end{array}$ & $\begin{array}{l}-1.90 \\
(0.46)\end{array}$ & $\begin{array}{l}-1.46^{* * *} \\
(0.10)\end{array}$ & & \\
\hline Lag2 & $\begin{array}{l}-0.28 \\
(0.24)\end{array}$ & & $\begin{array}{l}-1.46 \\
(0.44)\end{array}$ & $\begin{array}{l}-1.13 * * * \\
(0.12)\end{array}$ & & \\
\hline
\end{tabular}




\begin{tabular}{lclllll}
\hline Lag 3 & -0.47 & & -0.98 & $-0.44 * * *$ & & \\
& $(0.27)$ & & $(0.63)$ & $(0.10)$ & & \\
Lag4 & $0.34^{* * *}$ & $-0.30^{* * *}$ & -0.22 & & & \\
& $(0.10)$ & $(0.07)$ & $(0.25)$ & & $92.79 * *$ & \\
SIZE & 0.41 & $0.67 *$ & -1.80 & & $(25.69)$ & \\
& $(0.72)$ & $(0.34)$ & $(2.85)$ & & 0.78 & 0.16 \\
Adj. $\mathbf{R}^{2}$ & 0.81 & 0.82 & 0.84 & 0.93 & 20 & 20 \\
Obs. & 32 & 32 & 20 & 20 & 20 \\
\hline
\end{tabular}

Table 4. Regression on ROA (Continued)

\begin{tabular}{|c|c|c|c|c|c|c|}
\hline \multirow{2}{*}{$\begin{array}{l}\text { Company } \\
\text { Variables }\end{array}$} & \multicolumn{2}{|c|}{$\begin{array}{c}\text { Janfusun Fancyworld } \\
\text { Corp. (5701) }\end{array}$} & \multicolumn{2}{|c|}{$\begin{array}{c}\text { The Landis Taipei Hotel } \\
\text { Co., Ltd. (5703) }\end{array}$} & \multicolumn{2}{|c|}{$\begin{array}{c}\text { Hotel Royal } \\
\text { Chihpen(5704) }\end{array}$} \\
\hline & Model I & Model II & Model I & Model II & Model I & Model II \\
\hline Const. & $\begin{array}{c}29.91 \\
(30.30)\end{array}$ & $\begin{array}{l}-0.12 \\
(0.18)\end{array}$ & $\begin{array}{c}55.80 \\
(50.46)\end{array}$ & $\begin{array}{r}0.13 \\
(0.17)\end{array}$ & $\begin{array}{l}32.16^{*} \\
(19.05)\end{array}$ & $\begin{array}{r}0.00 \\
(0.12)\end{array}$ \\
\hline RMRF & $\begin{array}{r}0.04 \\
(0.05)\end{array}$ & & $\begin{array}{r}0.06 \\
(0.03)\end{array}$ & $\begin{array}{l}0.07^{* * *} \\
(0.02)\end{array}$ & $\begin{array}{l}0.05 * * \\
(0.02)\end{array}$ & $\begin{array}{l}0.03 * * \\
(0.01)\end{array}$ \\
\hline USD & $\begin{array}{l}-0.24 \\
(0.31)\end{array}$ & & $\begin{array}{r}0.10 \\
(0.24)\end{array}$ & & $\begin{array}{r}0.07 \\
(0.17)\end{array}$ & \\
\hline JPY & $\begin{array}{l}-0.01 \\
(0.08)\end{array}$ & & $\begin{array}{l}-0.11 \\
(0.08)\end{array}$ & & $\begin{array}{r}0.07 \\
(0.05)\end{array}$ & \\
\hline CNY & $\begin{array}{r}0.38 \\
(0.36)\end{array}$ & & $\begin{array}{r}0.10 \\
(0.27)\end{array}$ & & $\begin{array}{r}0.22 \\
(0.19)\end{array}$ & $\begin{array}{l}0.22 * * * \\
(0.07)\end{array}$ \\
\hline EUR & $\begin{array}{c}0.03 \\
(0.12)\end{array}$ & & $\begin{array}{l}-0.11 \\
(0.10)\end{array}$ & $\begin{array}{l}-0.12^{*} \\
(0.07)\end{array}$ & $\begin{array}{c}0.01 \\
(0.07)\end{array}$ & \\
\hline KRW & $\begin{array}{r}0.08 \\
(0.12)\end{array}$ & $\begin{array}{l}0.10^{*} \\
(0.05)\end{array}$ & $\begin{array}{r}0.07 \\
(0.09)\end{array}$ & & $\begin{array}{l}0.27 * * * \\
(0.07)\end{array}$ & $\begin{array}{l}0.17 * * * \\
(0.04)\end{array}$ \\
\hline GBP & $\begin{array}{l}-0.24 \\
(0.15)\end{array}$ & $\begin{array}{l}-0.16^{* *} \\
(0.06)\end{array}$ & $\begin{array}{r}0.00 \\
(0.10)\end{array}$ & & $\begin{array}{l}-0.09 \\
(0.07)\end{array}$ & \\
\hline SGD & $\begin{array}{r}0.29 \\
(0.37)\end{array}$ & & $\begin{array}{l}-0.05 \\
(0.24)\end{array}$ & & $\begin{array}{l}-0.31 * \\
(0.18)\end{array}$ & $\begin{array}{l}-0.29 * * * \\
(0.09)\end{array}$ \\
\hline AUD & $\begin{array}{l}-0.10 \\
(0.12)\end{array}$ & & $\begin{array}{l}0.22 * * \\
(0.09)\end{array}$ & $\begin{array}{l}0.20 * * * \\
(0.06)\end{array}$ & $\begin{array}{c}0.02 \\
(0.06)\end{array}$ & \\
\hline IDR & $\begin{array}{r}0.08 \\
(0.11)\end{array}$ & & $\begin{array}{l}-0.02 \\
(0.06)\end{array}$ & & $\begin{array}{l}-0.01 \\
(0.04)\end{array}$ & \\
\hline
\end{tabular}




\begin{tabular}{|c|c|c|c|c|c|c|}
\hline THB & $\begin{array}{l}-0.21 \\
(0.18)\end{array}$ & & $\begin{array}{l}-0.12 \\
(0.12)\end{array}$ & $\begin{array}{l}-0.20 * * \\
(0.08)\end{array}$ & $\begin{array}{c}0.00 \\
(0.09)\end{array}$ & \\
\hline MYR & $\begin{array}{r}0.06 \\
(0.17)\end{array}$ & & $\begin{array}{l}-0.17 \\
(0.13)\end{array}$ & & $\begin{array}{c}0.04 \\
(0.10)\end{array}$ & \\
\hline PHP & $\begin{array}{c}0.06 \\
(0.15)\end{array}$ & & $\begin{array}{l}-0.02 \\
(0.10)\end{array}$ & & $\begin{array}{l}-0.10 \\
(0.07)\end{array}$ & \\
\hline Lag1 & $\begin{array}{l}-0.65 * * \\
(0.28)\end{array}$ & $\begin{array}{l}-0.64 * * * \\
(0.16)\end{array}$ & $\begin{array}{l}-0.77 * * * \\
(0.12)\end{array}$ & $\begin{array}{l}-0.77 * * * \\
(0.09)\end{array}$ & $\begin{array}{l}-1.08 * * * \\
(0.15)\end{array}$ & $\begin{array}{l}-0.99 * * * \\
(0.09)\end{array}$ \\
\hline Lag2 & $\begin{array}{l}-0.31 \\
(0.36)\end{array}$ & $\begin{array}{l}-0.31^{*} \\
(0.16)\end{array}$ & $\begin{array}{l}-0.32 * * \\
(0.14)\end{array}$ & $\begin{array}{l}-0.35 * * * \\
(0.09)\end{array}$ & $\begin{array}{l}-0.83 * * * \\
(0.18)\end{array}$ & $\begin{array}{l}-0.66 * * * \\
(0.12)\end{array}$ \\
\hline Lag 3 & $\begin{array}{r}0.09 \\
(0.37)\end{array}$ & & $\begin{array}{c}0.01 \\
(0.13)\end{array}$ & & $\begin{array}{l}-0.71 * * * \\
(0.19)\end{array}$ & $\begin{array}{l}-0.56^{* * *} \\
(0.09)\end{array}$ \\
\hline Lag4 & $\begin{array}{c}0.14 \\
(0.26)\end{array}$ & & $\begin{array}{l}-0.07 \\
(0.11)\end{array}$ & & $\begin{array}{l}-0.11 \\
(0.16)\end{array}$ & \\
\hline SIZE & $\begin{array}{l}-1.35 \\
(1.36)\end{array}$ & & $\begin{array}{l}-2.68 \\
(2.41)\end{array}$ & & $\begin{array}{l}-1.58^{*} \\
(0.93)\end{array}$ & \\
\hline $\operatorname{Adj} . \mathbf{R}^{2}$ & 0.07 & 0.39 & 0.59 & 0.63 & 0.75 & 0.76 \\
\hline Obs. & 32 & 32 & 58 & 58 & 58 & 59 \\
\hline
\end{tabular}

In Table 4, almost all estimates of the lagged variables are significant and negative, such as, Leofoo Development Co., Ltd. (2705), Formosa International Hotels Corporation (2707), Janfusun Fancyworld Corp. (5701), The Landis Taipei Hotel Co., Ltd. (5703), and Hotel Royal Chihpen(5704).It implies that those $D_{1} R O A$ are mean-reverting. As the estimates of third-lagged variables are also significant, then we can conclude that there is a seasonal effect on the company's ROA.

Moreover, some estimates of SIZE are significant in Table 4. If it is positive, such as Chateau International Development Co., Ltd. (2722), then the company may increase its own assets to increase its $D_{1} R O A$, so to its ROA. Hence, it can operate efficiently by its assets to generate profit and then to be a well-performed company. If the estimate of SIZE is negative, such as those in Leofoo Development Co., Ltd. (2705) and FX Hotels Group Inc. (2724-F), then the company may dispose some of its idle assets or non-performed assets to reduce the inefficient effect of these assets. As a result, the company's ROA will be improved.

Next, Table 4 shows significant effects on the performances of Taiwan hotel industry due to the fluctuations of foreign exchange rates. The changes of foreign exchange rates have significant impacts on the $D_{1} R O A$ s. Some are positive and some are negative. The same currency has different impact on different companies. For example, Singapore dollar has 
positive effect on the $D_{1} R O A$ of Leofoo Development Co., Ltd. (2705), Chateau International Development Co., Ltd. (2722), and on the ROA of Ambassador Hotel Ltd. (2704), but negative effect on that of Pleasant Hotels International Inc.(2718) and Hotel Royal Chihpen (5704). Moreover, the Australian dollar has positive effect on the $D_{1} R O A$ of Formosa International Hotels Corporation (2707), Pleasant Hotels International Inc. (2718), and Landis Taipei Hotel Co., Ltd. (5703), and on the ROA of Ambassador Hotel Ltd. (2704), but negative effect on that of Chateau International Development Co., Ltd. (2722). And the Korean won has a positive effect on the $D_{1} R O A$ of Leofoo Development Co., Ltd. (2705), Janfusun Fancyworld Corp. (5701), Hotel Royal Chihpen (5704), and then on those company's ROA.

Furthermore, the number of significant variables and the component of significant variables are different to each company. For example, the significant variables of the Pleasant's $D_{1} R O A$ are the change of USD, CNY, EUR, SGD, AUD, IDR, THB, however, that of the Chateau's $D_{1} R O A$ are only the changes of Singapore dollar and Australia dollar. As a result, the portfolio of currencies should be different for each company.

Table 5. Regression on ROE

The regression model is given as follows:

$$
D_{1} R O E_{i, t}=\alpha_{i}+\beta_{i, m} \cdot R M R F_{t}+\sum_{k=1}^{p} \phi_{i, k} \cdot D_{1} R O E_{i, t-k}+\sum_{j=1}^{n} \gamma_{i, j} \cdot \Delta F X_{j, t}+\delta_{i} \cdot \text { Size }_{i, t}+a_{i, t} \cdot
$$

Model I regresses $D_{1} R O E_{, t} \equiv R O E_{, t}-R O E_{, t-1}$ on all exchange fluctuations, lagged variables and the control variables. Model II regresses $D_{1} R O E$ on all variables but selected by eliminating higher $p$-value explanatory variables. The values in the parentheses are standard error of the estimates. And $*, * *$ and $* * *$ stand for $10 \%, 5 \%$ and $1 \%$ level of significance, respectively.

\begin{tabular}{|c|c|c|c|c|c|c|}
\hline \multirow{2}{*}{$\begin{array}{l}\text { Company } \\
\text { Variables }\end{array}$} & \multicolumn{2}{|c|}{$\begin{array}{l}\text { Hotel Holiday } \\
\text { Garden (2702) }\end{array}$} & \multicolumn{2}{|c|}{$\begin{array}{c}\text { The Leofoo } \\
\text { Development Co., Ltd. } \\
(2705)\end{array}$} & \multicolumn{2}{|c|}{$\begin{array}{c}\text { Formosa International } \\
\text { HotelsCorporation (2707) }\end{array}$} \\
\hline & Model I & Model II & Model I & Model II & Model I & Model II \\
\hline Const. & $\begin{array}{c}8.39 \\
(10.97)\end{array}$ & $\begin{array}{r}0.14 \\
(0.13)\end{array}$ & $\begin{array}{r}550.62 \\
(305.52)\end{array}$ & $\begin{array}{l}232.88 * * \\
(110.24)\end{array}$ & $\begin{array}{c}28.18 \\
(15.24)\end{array}$ & $\begin{array}{r}0.10 \\
(0.21)\end{array}$ \\
\hline
\end{tabular}




\begin{tabular}{|c|c|c|c|c|c|c|}
\hline RMRF & $\begin{array}{c}0.01 \\
(0.02)\end{array}$ & & $\begin{array}{l}-0.07 \\
(0.21)\end{array}$ & & $\begin{array}{l}-0.03 \\
(0.04)\end{array}$ & \\
\hline USD & $\begin{array}{r}0.24 \\
(0.19)\end{array}$ & & $\begin{array}{l}-1.77 \\
(1.44)\end{array}$ & & $\begin{array}{l}0.05 \\
(0.31)\end{array}$ & \\
\hline JPY & $\begin{array}{c}0.05 \\
(0.05)\end{array}$ & $\begin{array}{l}0.08^{* *} \\
(0.03)\end{array}$ & $\begin{array}{l}-0.64 * \\
(0.33)\end{array}$ & $\begin{array}{l}-0.39 * * \\
(0.14)\end{array}$ & $\begin{array}{l}-0.12 \\
(0.08)\end{array}$ & $\begin{array}{l}-0.09^{*} \\
(0.05)\end{array}$ \\
\hline CNY & $\begin{array}{l}-0.16 \\
(0.20)\end{array}$ & & $\begin{array}{r}1.37 \\
(1.40)\end{array}$ & & $\begin{array}{l}-0.27 \\
(0.33)\end{array}$ & $\begin{array}{l}-0.25 * * \\
(0.11)\end{array}$ \\
\hline EUR & $\begin{array}{l}-0.11 \\
(0.08)\end{array}$ & $\begin{array}{l}-0.07 * \\
(0.04)\end{array}$ & $\begin{array}{l}-0.00 \\
(0.34)\end{array}$ & & $\begin{array}{l}-0.10 \\
(0.13)\end{array}$ & \\
\hline KRW & $\begin{array}{c}0.05 \\
(0.06)\end{array}$ & $\begin{array}{c}0.08^{*} \\
(0.04)\end{array}$ & $\begin{array}{c}0.47 \\
(0.46)\end{array}$ & & $\begin{array}{r}0.08 \\
(0.11)\end{array}$ & \\
\hline GBP & $\begin{array}{r}0.00 \\
(0.07)\end{array}$ & & $\begin{array}{l}-0.19 \\
(0.42)\end{array}$ & & $\begin{array}{l}-0.04 \\
(0.12)\end{array}$ & \\
\hline SGD & $\begin{array}{c}0.22 \\
(0.20)\end{array}$ & & $\begin{array}{l}4.02 * * \\
(1.70)\end{array}$ & $\begin{array}{l}1.74 * * \\
(0.62)\end{array}$ & $\begin{array}{r}0.34 \\
(0.34)\end{array}$ & $\begin{array}{l}0.39 * * \\
(0.19)\end{array}$ \\
\hline AUD & $\begin{array}{l}-0.00 \\
(0.20)\end{array}$ & & $\begin{array}{l}-0.63 \\
(0.50)\end{array}$ & & $\begin{array}{r}0.06 \\
(0.10)\end{array}$ & \\
\hline IDR & $\begin{array}{c}0.02 \\
(0.05)\end{array}$ & & $\begin{array}{c}0.12 \\
(0.28)\end{array}$ & & $\begin{array}{l}-0.13^{*} \\
(0.07)\end{array}$ & $\begin{array}{l}-0.09 * \\
(0.05)\end{array}$ \\
\hline ТHB & $\begin{array}{c}0.11 \\
(0.09)\end{array}$ & $\begin{array}{l}0.10^{*} \\
(0.06)\end{array}$ & $\begin{array}{l}-0.52 \\
(0.77)\end{array}$ & & $\begin{array}{c}0.02 \\
(0.16)\end{array}$ & \\
\hline MYR & $\begin{array}{l}-0.06 \\
(0.11)\end{array}$ & & $\begin{array}{l}-1.36^{* *} \\
(0.56)\end{array}$ & $\begin{array}{l}-0.68 * * \\
(0.29)\end{array}$ & $\begin{array}{l}-0.01 \\
(0.18)\end{array}$ & \\
\hline PHP & $\begin{array}{l}-0.11 \\
(0.08)\end{array}$ & & $\begin{array}{c}0.92 \\
(1.24)\end{array}$ & & $\begin{array}{r}0.05 \\
(0.13)\end{array}$ & \\
\hline Lag1 & $\begin{array}{l}-0.90 * * * \\
(0.15)\end{array}$ & $\begin{array}{l}-0.88^{* * *} \\
(0.12)\end{array}$ & $\begin{array}{l}-1.27^{* * *} \\
(0.37)\end{array}$ & $\begin{array}{l}-0.64 * * * \\
(0.18)\end{array}$ & $\begin{array}{l}-0.61 * * * \\
(0.15)\end{array}$ & $\begin{array}{l}-0.61 * * * \\
(0.12)\end{array}$ \\
\hline Lag2 & $\begin{array}{l}-0.67 * * * \\
(0.19)\end{array}$ & $\begin{array}{l}-0.58 * * \\
(0.15)\end{array}$ & $\begin{array}{l}-0.15 \\
(0.43)\end{array}$ & & $\begin{array}{l}-0.66^{* * *} \\
(0.16)\end{array}$ & $\begin{array}{l}-0.63 * * * \\
(0.12)\end{array}$ \\
\hline Lag 3 & $\begin{array}{l}0.41 * * \\
(0.19)\end{array}$ & $\begin{array}{l}-0.42^{* * *} \\
(0.18)\end{array}$ & $\begin{array}{r}0.20 \\
(0.33)\end{array}$ & & $\begin{array}{l}-0.49 * * * \\
(0.16)\end{array}$ & $\begin{array}{l}-0.46^{* * *} \\
(0.12)\end{array}$ \\
\hline Lag4 & $\begin{array}{l}-0.04 \\
(0.15)\end{array}$ & & $\begin{array}{c}0.33 \\
(0.28)\end{array}$ & & $\begin{array}{l}-0.01 \\
(0.16)\end{array}$ & \\
\hline SIZE & $\begin{array}{l}-0.39 \\
(0.57)\end{array}$ & & $\begin{array}{l}-24.32 \\
(13.46)\end{array}$ & $\begin{array}{l}-10.28 * * \\
(4.86)\end{array}$ & $\begin{array}{l}-1.26 \\
(1.13)\end{array}$ & \\
\hline Adj. $R^{2}$ & 0.51 & 0.54 & 0.16 & 0.32 & 0.30 & 0.39 \\
\hline
\end{tabular}


Obs.

58

58

27

27

58

58

Table 5. Regression on ROE (Continued)

\begin{tabular}{|c|c|c|c|c|c|c|}
\hline \multirow{2}{*}{$\begin{array}{l}\text { Company } \\
\text { Variables }\end{array}$} & \multicolumn{2}{|c|}{$\begin{array}{c}\text { First Hotel Company } \\
\text { Ltd. (2706) }\end{array}$} & \multicolumn{2}{|c|}{$\begin{array}{c}\text { Pleasant Hotels } \\
\text { International } \\
\text { Inc.(2718) } \\
\end{array}$} & \multicolumn{2}{|c|}{$\begin{array}{c}\text { Chateau International } \\
\text { Development Co., Ltd. } \\
(2722) \\
\end{array}$} \\
\hline & Model I & Model II & Model I & Model II & Model I & Model II \\
\hline Const. & $\begin{array}{l}-21.59 \\
(37.72)\end{array}$ & $\begin{array}{l}0.84 * * \\
(0.38)\end{array}$ & $\begin{array}{c}31.69 \\
(89.17)\end{array}$ & $\begin{array}{l}0.98^{* * * *} \\
(0.18)\end{array}$ & $\begin{array}{l}-2289 * * \\
(737.7)\end{array}$ & $\begin{array}{l}-0.44 \\
(1.05)\end{array}$ \\
\hline RMRF & $\begin{array}{c}0.05^{*} \\
(0.02)\end{array}$ & $\begin{array}{l}0.05^{* * *} \\
(0.01)\end{array}$ & $\begin{array}{l}-0.15 \\
(0.15)\end{array}$ & $\begin{array}{l}-0.08^{*} \\
(0.04)\end{array}$ & $\begin{array}{l}3.87 * * \\
(1.08)\end{array}$ & \\
\hline USD & $\begin{array}{l}0.39 * * \\
(1.74)\end{array}$ & $\begin{array}{l}0.12 * * * \\
(0.04)\end{array}$ & $\begin{array}{c}1.77 \\
(1.66)\end{array}$ & $\begin{array}{l}0.85^{* * * *} \\
(0.21)\end{array}$ & $\begin{array}{l}-15.42^{* *} \\
(5.71)\end{array}$ & \\
\hline JPY & $\begin{array}{r}0.04 \\
(0.03)\end{array}$ & & $\begin{array}{l}-0.02 \\
(0.18)\end{array}$ & & $\begin{array}{l}3.60 * * \\
(1.03)\end{array}$ & \\
\hline $\mathrm{CNY}$ & $\begin{array}{l}-0.31 * \\
(0.16)\end{array}$ & & $\begin{array}{l}-1.61 \\
(1.12)\end{array}$ & $\begin{array}{l}-1.04 * * * \\
(0.21)\end{array}$ & $\begin{array}{l}14.08 * * \\
(5.14)\end{array}$ & \\
\hline EUR & $\begin{array}{l}-0.05 \\
(0.05)\end{array}$ & & $\begin{array}{l}-0.37 \\
(0.31)\end{array}$ & $\begin{array}{l}-0.24 * * * \\
(0.06)\end{array}$ & $\begin{array}{l}8.86^{* *} \\
(2.67)\end{array}$ & \\
\hline KRW & $\begin{array}{l}-0.04 \\
(0.05)\end{array}$ & & $\begin{array}{r}0.24 \\
(0.35)\end{array}$ & & $\begin{array}{l}-6.07 * * \\
(2.03)\end{array}$ & \\
\hline GBP & $\begin{array}{c}0.01 \\
(0.06)\end{array}$ & & $\begin{array}{l}-0.35 \\
(0.63)\end{array}$ & & $\begin{array}{l}-7.56^{* *} \\
(2.03)\end{array}$ & \\
\hline SGD & $\begin{array}{r}0.03 \\
(0.14)\end{array}$ & & $\begin{array}{l}-0.76 \\
(0.72)\end{array}$ & $\begin{array}{l}-0.86^{* * *} \\
(0.15)\end{array}$ & $\begin{array}{r}1.93 \\
(1.00)\end{array}$ & $\begin{array}{l}2.46^{* *} \\
(1.05)\end{array}$ \\
\hline AUD & $\begin{array}{r}0.03 \\
(0.05)\end{array}$ & & $\begin{array}{c}0.25 \\
(0.21)\end{array}$ & $\begin{array}{l}0.16^{* *} \\
(0.07)\end{array}$ & $\begin{array}{l}-5.22 * * * \\
(1.24)\end{array}$ & $\begin{array}{l}-0.77 * * \\
(0.36)\end{array}$ \\
\hline IDR & $\begin{array}{l}-0.04 \\
(0.05)\end{array}$ & & $\begin{array}{c}0.27 \\
(0.13)\end{array}$ & $\begin{array}{l}0.29 * * * \\
(0.05)\end{array}$ & $\begin{array}{c}0.77^{*} \\
(0.32)\end{array}$ & \\
\hline ТНB & $\begin{array}{c}0.05 \\
(0.07)\end{array}$ & & $\begin{array}{r}0.77 \\
(0.50)\end{array}$ & $\begin{array}{l}0.74 * * * \\
(0.17)\end{array}$ & $\begin{array}{l}-15.90 * * \\
(4.38)\end{array}$ & \\
\hline MYR & $\begin{array}{l}-0.04 \\
(0.06)\end{array}$ & & $\begin{array}{l}-0.13 \\
(0.25)\end{array}$ & & $\begin{array}{l}4.41^{* *} \\
(1.30)\end{array}$ & \\
\hline PHP & $\begin{array}{l}-0.08 \\
(0.11)\end{array}$ & & $\begin{array}{l}-1.32 \\
(0.67)\end{array}$ & $\begin{array}{l}-0.93 * * * \\
(0.23)\end{array}$ & $\begin{array}{l}21.70 * * \\
(6.56)\end{array}$ & \\
\hline
\end{tabular}




\begin{tabular}{|c|c|c|c|c|c|c|}
\hline Lag1 & $\begin{array}{l}-1.37 * * * \\
(0.18)\end{array}$ & $\begin{array}{l}-2.88 * * * \\
(0.37)\end{array}$ & $\begin{array}{l}-1.88 \\
(0.55)\end{array}$ & $\begin{array}{l}-1.48 * * * \\
(0.12)\end{array}$ & & \\
\hline Lag2 & $\begin{array}{l}-0.31 \\
(0.21)\end{array}$ & $\begin{array}{l}-0.82 * * \\
(0.40)\end{array}$ & $\begin{array}{l}-1.50 \\
(0.55)\end{array}$ & $\begin{array}{l}-1.15^{* * *} \\
(0.13)\end{array}$ & & \\
\hline Lag 3 & $\begin{array}{l}-0.19 \\
(0.24)\end{array}$ & & $\begin{array}{l}-0.99 \\
(0.80)\end{array}$ & $\begin{array}{l}-0.44 * * * \\
(0.11)\end{array}$ & & \\
\hline Lag4 & $\begin{array}{l}0.50 * * \\
(0.21)\end{array}$ & $\begin{array}{l}1.86 * * * \\
(0.36)\end{array}$ & $\begin{array}{l}-0.21 \\
(0.29)\end{array}$ & & & \\
\hline SIZE & $\begin{array}{r}1.06 \\
(1.74)\end{array}$ & & $\begin{array}{l}-1.51 \\
(4.37)\end{array}$ & & $\begin{array}{l}108.51 * * \\
(34.93)\end{array}$ & \\
\hline Adj. $R^{2}$ & 0.87 & 0.85 & 0.77 & 0.92 & 0.74 & 0.18 \\
\hline Obs. & 28 & 31 & 20 & 20 & 20 & 20 \\
\hline
\end{tabular}

Table 5. Regression on ROE (Continued)

\begin{tabular}{|c|c|c|c|c|c|c|}
\hline \multirow{2}{*}{$\begin{array}{l}\text { Company } \\
\text { Variables }\end{array}$} & \multicolumn{2}{|c|}{$\begin{array}{c}\text { Janfusun Fancyworld } \\
\text { Corp. (5701) }\end{array}$} & \multicolumn{2}{|c|}{$\begin{array}{c}\text { The Landis Taipei Hotel } \\
\text { Co., Ltd. (5703) }\end{array}$} & \multicolumn{2}{|c|}{$\begin{array}{c}\text { Hotel Royal } \\
\text { Chihpen(5704) }\end{array}$} \\
\hline & Model I & Model II & Model I & Model II & Model I & Model II \\
\hline Const. & $\begin{array}{r}55.72 \\
(141.90)\end{array}$ & $\begin{array}{r}0.04 \\
(0.42)\end{array}$ & $\begin{array}{r}70.20 \\
(69.75)\end{array}$ & $\begin{array}{l}-0.28 \\
(0.23)\end{array}$ & $\begin{array}{l}39.26^{*} \\
(21.32)\end{array}$ & $\begin{array}{r}0.02 \\
(0.14)\end{array}$ \\
\hline RMRF & $\begin{array}{r}0.09 \\
(0.33)\end{array}$ & & $\begin{array}{r}0.07 \\
(0.04)\end{array}$ & & $\begin{array}{l}0.06 * * \\
(0.02)\end{array}$ & $\begin{array}{l}0.04 * * \\
(0.02)\end{array}$ \\
\hline USD & $\begin{array}{c}0.11 \\
(1.45)\end{array}$ & & $\begin{array}{r}0.17 \\
(0.33)\end{array}$ & & $\begin{array}{r}0.04 \\
(0.19)\end{array}$ & \\
\hline JPY & $\begin{array}{r}0.12 \\
(0.35)\end{array}$ & & $\begin{array}{l}-0.15 \\
(0.10)\end{array}$ & $\begin{array}{l}-0.15^{* *} \\
(0.06)\end{array}$ & $\begin{array}{r}0.08 \\
(0.05)\end{array}$ & \\
\hline CNY & $\begin{array}{c}0.01 \\
(1.23)\end{array}$ & & $\begin{array}{c}0.11 \\
(0.37)\end{array}$ & & $\begin{array}{r}0.28 \\
(0.21)\end{array}$ & $\begin{array}{l}0.25^{* * *} \\
(0.08)\end{array}$ \\
\hline EUR & $\begin{array}{r}0.12 \\
(0.45)\end{array}$ & & $\begin{array}{l}-0.15 \\
(0.14)\end{array}$ & $\begin{array}{l}-0.25 * * * \\
(0.09)\end{array}$ & $\begin{array}{r}0.02 \\
(0.08)\end{array}$ & \\
\hline KRW & $\begin{array}{r}0.37 \\
(0.72)\end{array}$ & & $\begin{array}{r}0.08 \\
(0.12)\end{array}$ & & $\begin{array}{l}0.30 * * * \\
(0.07)\end{array}$ & $\begin{array}{l}0.18 * * * \\
(0.05)\end{array}$ \\
\hline GBP & $\begin{array}{l}-0.59 \\
(0.43)\end{array}$ & $\begin{array}{l}-0.31 * * \\
(0.14)\end{array}$ & $\begin{array}{l}-0.02 \\
(0.14)\end{array}$ & & $\begin{array}{l}-0.09 \\
(0.08)\end{array}$ & \\
\hline SGD & $\begin{array}{c}0.16 \\
(1.00)\end{array}$ & & $\begin{array}{l}-0.09 \\
(0.33)\end{array}$ & & $\begin{array}{l}-0.36^{*} \\
(0.20)\end{array}$ & $\begin{array}{l}-0.32 * * * \\
(0.10)\end{array}$ \\
\hline
\end{tabular}




\begin{tabular}{lclllll}
\hline AUD & -0.51 & $-0.22^{*}$ & $0.30^{* *}$ & $0.39^{* * * *}$ & 0.01 & \\
& $(0.37)$ & $(0.11)$ & $(0.12)$ & $(0.07)$ & $(0.06)$ & \\
IDR & 0.23 & & -0.03 & & -0.01 & \\
& $(0.33)$ & & $(0.08)$ & & $(0.05)$ & \\
THB & -0.42 & & -0.11 & & -0.00 & \\
& $(0.66)$ & & $(0.17)$ & & $(0.10)$ & \\
MYR & 0.51 & $0.36^{*}$ & -0.23 & $-0.24 * *$ & 0.05 & \\
& $(0.48)$ & $(0.20)$ & $(0.18)$ & $(0.11)$ & $(0.11)$ & \\
PHP & 0.20 & & -0.03 & & -0.11 & \\
& $(1.13)$ & & $(0.14)$ & & $(0.08)$ & \\
Lag1 & $-0.60 *$ & $-0.75 * * *$ & $-0.76^{* * *}$ & $-0.75 * * *$ & $-1.09 * * *$ & $-0.99 * * *$ \\
& $(0.31)$ & $(0.17)$ & $(0.13)$ & $(0.09)$ & $(0.14)$ & $(0.09)$ \\
Lag2 & -0.29 & $-0.52^{* * *}$ & $-0.35 * *$ & $-0.42^{* * *}$ & $-0.83 * * *$ & $-0.66 * * *$ \\
& $(0.43)$ & $(0.17)$ & $(0.15)$ & $(0.09)$ & $(0.19)$ & $(0.12)$ \\
Lag 3 & 0.30 & & -0.01 & & $-0.73 * * *$ & $-0.56 * * *$ \\
Lag4 & $(0.73)$ & & $(0.13)$ & & $(0.19)$ & $(0.09)$ \\
Adj. R & 0.26 & & -0.08 & & -0.12 & \\
Obs. & 0.04 & 0.48 & 0.57 & 0.61 & 0.76 & 0.77 \\
\hline
\end{tabular}

In Table 5, Model I regresses $D_{1} R O E$ on all exchange fluctuations, lagged variables and the control variables. Model II regresses $D_{1} R O E$ on all variables but selected by eliminating higher $p$-value explanatory variables. We may find that the results in Table 5 are almost the same as in Table 4. There is seasonal effect for Taiwan hotel industry's ROE, too. And, $D_{1} R O E$ of First Hotel Company Ltd. (2706) and Pleasant Hotels International Inc. (2718) are mean-reverting. Moreover, the number of significant variables and the component of significant variables are different to each company. For example, the significant variables of the ROE of Landis Taipei Hotel Co., Ltd. (5703) are the changes of euro, Japan yen, Australia dollar and Malaysian Ringgit, but that of the Chateau International Development Co., Ltd. (2722) are the changes of euro, pound, Chinese yuan, Japan yen, Korean won, Singapore dollar, Australia dollar, Thailand Baht, Malaysian Ringgit, and Philippine peso. Therefore, it supports the results in Table 4, which the portfolio of currencies should be different for each company. 
Table 6. Regression on Financial Performances of the Ambassador Hotel

The regression model is given as follows:

$y_{2704, t}=\alpha_{2704}+\beta_{2704, m} \cdot R M R F_{t}+\sum_{k=1}^{p} \phi_{2704, k} \cdot y_{2704, t-k}+\sum_{j=1}^{n} \gamma_{2704, j} \cdot \Delta F X_{j, t}+\delta_{i} \cdot$ Size $_{2704, t}+a_{2704, t} \cdot$

$y_{2704}$ represents the performance of the Ambassador Hotel, that is, $R O A_{2704}$ or $R O E_{2704}$. Model I regresses $y_{2704}$ on all exchange fluctuations, lagged variables and the control variables. Model II regresses $y_{2704}$ on all variablesbut selected by eliminating higher $p$-value explanatory variables. The values in the parentheses are standard error of the estimates. And $*, * *$ and $* * *$ stand for $10 \%, 5 \%$ and $1 \%$ level of significance, respectively.

\begin{tabular}{|c|c|c|c|c|}
\hline Performance & & $A_{2704}$ & & $E_{2704}$ \\
\hline Variables & Model I & Model II & Model I & Model II \\
\hline Const. & $\begin{array}{l}-25.80 \\
(34.26)\end{array}$ & $\begin{array}{l}0.28 * * \\
(0.11)\end{array}$ & $\begin{array}{l}-34.80 \\
(58.29)\end{array}$ & $\begin{array}{c}0.25^{*} \\
(0.14)\end{array}$ \\
\hline RMRF & $\begin{array}{c}0.02 \\
(0.01)\end{array}$ & $\begin{array}{l}0.15^{* *} \\
(0.01)\end{array}$ & $\begin{array}{c}0.03 \\
(0.02)\end{array}$ & $\begin{array}{l}0.03 * * * \\
(0.01)\end{array}$ \\
\hline USD & $\begin{array}{l}-0.21 * * \\
(0.09)\end{array}$ & & $\begin{array}{l}-0.32^{* *} \\
(0.15)\end{array}$ & \\
\hline JPY & $\begin{array}{c}0.01 \\
(0.02)\end{array}$ & & $\begin{array}{r}0.02 \\
(0.03)\end{array}$ & \\
\hline CNY & $\begin{array}{l}0.22 * * \\
(0.09)\end{array}$ & & $\begin{array}{l}0.34 * * \\
(0.16)\end{array}$ & \\
\hline EUR & $\begin{array}{l}-0.05 \\
(0.03)\end{array}$ & $\begin{array}{l}-0.05 * * \\
(0.02)\end{array}$ & $\begin{array}{l}-0.08 \\
(0.06)\end{array}$ & $\begin{array}{l}-0.08 * * \\
(0.03)\end{array}$ \\
\hline KRW & $\begin{array}{c}0.01 \\
(0.03)\end{array}$ & & $\begin{array}{r}0.03 \\
(0.05)\end{array}$ & \\
\hline GBP & $\begin{array}{r}0.04 \\
(0.03)\end{array}$ & & $\begin{array}{r}0.06 \\
(0.06)\end{array}$ & \\
\hline SGD & $\begin{array}{c}0.10 \\
(0.10)\end{array}$ & $\begin{array}{c}0.14^{* *} \\
(0.06)\end{array}$ & $\begin{array}{r}0.17 \\
(0.17)\end{array}$ & $\begin{array}{l}0.26^{* *} \\
(0.10)\end{array}$ \\
\hline AUD & $\begin{array}{l}-0.02 \\
(0.03)\end{array}$ & & $\begin{array}{l}-0.05 \\
(0.05)\end{array}$ & \\
\hline IDR & $\begin{array}{c}0.01 \\
(0.02)\end{array}$ & & $\begin{array}{r}0.02 \\
(0.04)\end{array}$ & \\
\hline THB & $\begin{array}{c}0.02 \\
(0.04)\end{array}$ & & $\begin{array}{r}0.04 \\
(0.07)\end{array}$ & \\
\hline MYR & $\begin{array}{l}-0.11^{* *} \\
(0.05)\end{array}$ & $\begin{array}{l}-0.10 * * * \\
(0.04)\end{array}$ & $\begin{array}{l}-0.18 * * \\
(0.08)\end{array}$ & $\begin{array}{l}-0.17 * * * \\
(0.06)\end{array}$ \\
\hline
\end{tabular}




\begin{tabular}{lccc} 
Macrothink & \multicolumn{2}{c}{ Asian Journal of Finance \& Accounting } \\
ISSN 1946-052X \\
2017, Vol. 9, No. 1
\end{tabular}

Next, because Taiwan's foreign trade is mainly denominated in US dollars, Taiwan foreign exchange market for a long time pegged to the dollar exchange rate. Therefore, enterprises may have a greater proportion of dollar holdings. Furthermore, due to the opening of Chinese tourists to Taiwan, it results in the hotel industry to increase its Chinese yuan transaction needs, and thus ROA/ROE reflect the effect from the change of Chinese yuan. In additional, Taiwan is also the first choice for Japanese and Korean tourists traveling abroad, so accommodation of the Korean won and the Japanese yen in trading volume should not be underestimated.

As shown in Table 7, major hotels aggregated by Taiwan's Tourism Bureau in 2012 showed that the Japanese and Korean inbounds were over 1/5 of guests in the half of the hotels. For example, Pleasant Hotel located closed to the Taoyuan International Airport, and most Chinese tourists stay at the hotel in order to conveniently entry and exit. Both Jang and Chen (2008) and Chen, Jang and Peng (2011) employed the modern portfolio theory to investigate the mixes of Taiwan inbounds. They suggested that the government should take the high-reward/high-volatility option and shift more available resources to attract the Japanese tourists. 
Table 7. Distribution of guests' sources in 2012

\begin{tabular}{|c|c|c|c|c|c|c|c|c|}
\hline Region & $\begin{array}{l}\text { Royal } \\
\text { Hotel }\end{array}$ & $\begin{array}{c}\text { Pleasant } \\
\text { Hotels } \\
\text { (Taoyuan) }\end{array}$ & $\begin{array}{c}\text { Ambassa } \\
\text { dor } \\
\text { Hotel }\end{array}$ & $\begin{array}{l}\text { Landis } \\
\text { Taipei } \\
\text { Hotel }\end{array}$ & $\begin{array}{l}\text { Formosa } \\
\text { Internatio } \\
\text { nal Hotels }\end{array}$ & $\begin{array}{l}\text { Leofoo } \\
\text { Westin } \\
\text { Hotel }\end{array}$ & $\begin{array}{l}\text { Holiday } \\
\text { Garden } \\
\text { Hotel }\end{array}$ & $\begin{array}{l}\text { Farglory } \\
\text { Hotel }\end{array}$ \\
\hline Domestic & 55.2 & 18.0 & 34.0 & 24.2 & 21.3 & 9.7 & 61.2 & 94.9 \\
\hline $\begin{array}{l}\text { Oversea } \\
\text { Chinese }\end{array}$ & 0.0 & 7.7 & 1.9 & 6.4 & 0.0 & 0.0 & 1.0 & 0.0 \\
\hline Mainland & 6.35 & 56.35 & 13.29 & 11.08 & 11.5 & 19.4 & 22.45 & 3.9 \\
\hline $\begin{array}{l}\text { North } \\
\text { American }\end{array}$ & 4.7 & 0.3 & 6.9 & 10.3 & 8.4 & 20.8 & 0.8 & 0.2 \\
\hline Japan & 21.9 & 2.1 & 29.9 & 29.9 & 36.7 & 17.3 & 7.0 & 0.1 \\
\hline $\begin{array}{l}\text { Asian } \\
\text { (exclusive } \\
\text { Japanese) }\end{array}$ & 5.0 & 9.2 & 8.2 & 8.4 & 15.3 & 25.9 & 6.5 & 0.5 \\
\hline European & 2.5 & 0.3 & 3.8 & 7.5 & 4.7 & 4.3 & 0.5 & 0.1 \\
\hline Australia & 0.3 & 0.0 & 0.4 & 1.8 & 0.9 & 1.4 & 0.5 & 0.0 \\
\hline Others & 4.1 & 6.1 & 1.6 & 0.4 & 1.2 & 1.2 & 0.0 & 0.3 \\
\hline Total (\%) & 100 & 100 & 100 & 100 & 100 & 100 & 100 & 100 \\
\hline
\end{tabular}

Source: Tourism Bureau, M.O.T.C., Republic of China (Taiwan).

Kim (2013) discussed of foreign exchange position and make recommendations in Table 8.In Table 4,5, and 6, a portfolio of currencies that has significant impacts on the company's ROA/ ROE can be formed. Markowitz (1952) proposed the Modern portfolio theory that based on the weighted each company the average cost of capital (WACC), and along with the calculation of Matlab programs for foreign exchange positions, an optimum allocation of currencies can reach the lowest degree of risk under a pre-specified rate of return constraint. 


\section{Macrothink}

Table 8. Optimal Portfolio of Foreign Currencies for each company.

\begin{tabular}{rrrrrrr}
\hline Company & $\mathbf{2 7 0 2}$ & $\mathbf{2 7 0 4}$ & $\mathbf{2 7 0 5}$ & $\mathbf{2 7 0 6}$ & $\mathbf{2 7 0 7}$ & $\mathbf{2 7 1 8}$ \\
\hline USD & & & & 0.00 & & 6.35 \\
\hline GBP & & & & 62.18 & & \\
\hline EUR & 20.47 & 13.79 & & & & \\
\hline JPY & 2.32 & & 1.30 & 2.09 & 0.00 \\
\hline KRW & 3.84 & & 1.56 & 30.56 & & \\
\hline CNY & & & & 0.00 & 19.47 & 0.00 \\
\hline AUD & 52.35 & & 83.81 & & 74.37 & \\
\hline SGD & & 84.35 & 3.84 & & & 0.00 \\
\hline IDR & 1.73 & & & & 6.16 & 7.14 \\
\hline MYR & THB & 1.85 & 9.94 & 5.17 & & 5.53 \\
\hline PHP & & & & & & 0.00 \\
\hline & & & & 0.00 & & 7.19 \\
\hline $\begin{array}{l}\text { WACC } \\
\text { (\%) }\end{array}$ & 10.00 & 12.00 & 13.50 & 12.80 & 9.50 & 12.60 \\
\hline Portfolio risk (\%) & 0.431 & 1.850 & 0.513 & 2.501 & 0.356 & 0.458 \\
\hline
\end{tabular}


Table 8. Optimal Portfolio of Foreign Currencies for each company. (Continued)

\begin{tabular}{|c|c|c|c|c|c|c|}
\hline Currency & 2722 & 2724 & 5701 & 5703 & 5704 & Full \\
\hline USD & 3.27 & 2.26 & & & & 0.00 \\
\hline GBP & & & 2.24 & & 34.33 & 0.29 \\
\hline EUR & & & & 6.04 & & 44.14 \\
\hline JPY & 0.00 & 0.00 & & 0.11 & & 0.00 \\
\hline KRW & 6.07 & 0.31 & 0.76 & & 14.90 & 0.07 \\
\hline CNY & 5.17 & 4.47 & & & 13.80 & 1.49 \\
\hline AUD & 73.79 & 82.84 & 85.53 & 79.93 & & 9.41 \\
\hline SGD & 0.00 & 0.00 & & & 0.00 & 0.00 \\
\hline IDR & & 5.47 & & & 36.97 & 0.52 \\
\hline MYR & & 4.66 & 11.47 & 13.03 & & 0.64 \\
\hline THB & & & & 0.90 & & 0.00 \\
\hline PHP & & & & & & 43.44 \\
\hline $\begin{array}{c}\text { WACC } \\
(\%)\end{array}$ & 10.60 & 9.80 & 13.20 & 11.50 & 9.80 & 12.20 \\
\hline $\begin{array}{l}\text { Portfolio } \\
\text { risk (\%) }\end{array}$ & 0.515 & 0.481 & 0.520 & 0.476 & 2.062 & 0.055 \\
\hline
\end{tabular}

The results in Table 8 show the optimal allocation of currencies for each company. Japanese yen, Korean won, Chinese Yuan, Australian dollar and Malaysian Ringgit configuration still play significant roles among those target companies, including Leofoo Development Co., Ltd. (2705), Formosa International Hotels Corporation (2707),Pleasant Hotels International Inc.(2718), Chateau International Development Co., Ltd. (2722), FX Hotels Group Inc. (2724-F), Janfusun Fancyworld Corp. (5701), The Landis Taipei Hotel Co., Ltd. (5703). The configuration of the Australian dollar reached 52.35\%, 83.81\%, 44.37\%, 73.79\%,85.48\%, $82.84 \%, 85.53 \%$ and $79.93 \%$, respectively, more than $50 \%$ have switched. Hotel Holiday Garden(2702), Leofoo Development Co., Ltd. (2705), First Hotel Company Ltd. (2706), Chateau International Development Co., Ltd. (2722),FX Hotels Group Inc. (2724-F), Janfusun Fancyworld Corp. (5701), and Landis Taipei Hotel Co., Ltd.(5703) for the Korean 
won configuration, respectively, 3.84\%, $1.56 \%, 30.56 \%, 6.07 \%, 0.31 \%, 0.76 \%$, and 14.90 . As to Chinese yuan, Formosa International Hotels Corporation (2707), Chateau International Development Co., Ltd. (2722), FX Hotels Group Inc. (2724-F), and Hotel Royal Chihpen(5704) should put the weight ranging from $4.47 \%$ to $19.47 \%$.

\section{Conclusions}

In recent years, the changes in exchange rates significantly affect a company's performances, such as, ROE, ROA, etc. Faced with the dramatic changes in the international economic environment, many central banks continue to adopt a more aggressive monetary policy, such as, negative interest rates by Bank of Japan, the monetary easing by ECB, and monetary easing by People's Bank of China. Likewise, the gradual recovery of the economy of the United States have taken actions to raise interest rates. The auspices of monetary policy in these countries shows that the currencies flow across countries and international hot money have allowed changes in exchange rates. Under these actions of monetary policies, enterprises in Taiwan need to actively adopt configuration to reduce the negative impact.

Changes in the foreign exchange market in the past is not as dramatic as in today. In addition to monetary policies that attract more investors to the market, the investment of foreign exchange market as well significantly affect the change in exchange rates among countries. Therefore, a positive formal foreign exchange risk management will better help for future operation, which can significantly reduce the risk of foreign exchange movements.

This study found that hotels in Taiwan, accounting for the largest part of the tourism industry, are subject to have the impacts on their performance and profitability due to the exchange rate fluctuations. Enterprises may apply the results to manage their foreign exchange risk exposure, and then increase the overall capabilities and range of enterprise risk management (ERM).By doing so, companies can increase their profits and reduce the negative impacts of exchange rate changes on corporate ROE/ROA through foreign exchange operations. More importantly, foreign exchange allocation can be a strategy to reduce the risk of foreign exchange exposure.

\section{References}

Addae A. A., M. Nyark-Baasi, \& M. Tetteh. (2014). Effect of exchange rate movements on Ghanaian banks. Journal of Finance and Accounting, 2(3), 62-71. https://doi.org/10.11648/j.jfa.20140203.15.s

Adler, M., \& B., Dumas. (1980). The exposure of long-term foreign currency bonds. Journal of Financial and Quantitative Analysis, 15(4), 973-995. https://doi.org/10.2307/2330573.

Adler, M., \& B., Dumas. (1984). Exposure to currency risks: Definition andMeasurement. Financial Management, 13(2), 41-50. https://doi.org/10.2307/3665446.

Aggarwal, R., \& J. T. Harper. (2010). Foreign exchange exposure of "domestic" corporations. Journal of International Money and Finance, 29(8), 1619-1636. https://doi.org/10.1016/j.jimonfin.2010.05.003. 
Anderson, T. D., \& D. Getz, (2009). Tourism as a mixed industry: Differences between private, public and not-for-profit festivals. Tourism Management, 30(6), 847-856. https://doi.org/10.1016/j.tourman.2008.12.008.

Bailey, W., E. Ng, \& R. M. Stulz, (1992). Optimal hedging of stock portfolios against foreign exchange risk: theory and applications. Global Finance Journal, 3(2), pp.97-113. https://doi.org/10.1016/1044-0283(92)90007-8.

Bartram, S. M. (2008). What lies beneath: Foreign exchange rate exposure, hedging and cash flows. Journal of Banking \& Finance, 32(8), 1508-1521. https://doi.org/10.1016/j.jbankfin.2007.07.013.

Bodie Z., A. Kane, \& A. Marcus, (2002). Investment. McGraw Hill, New York. ISBN-13: 978-0073530703.

Bodnar, G. M., \& W. M., Gentry, (1993). Exchange rate exposure and industry characteristics: Evidence from Canada, Japan, and the USA. Journal of International Money and Finance, 12(1), 29-45. 10.1016/0261-5606(93)90008-Y.

Candela G., \& P. Figini, (2012). The Economics of Tourism Destinations. Springer Texts in Business and Economics. McGraw-Hill Companies Inc., Heidelberg. ISBN: 978-3-642-20874-4.

Campbell, J. Y., K. S., Medeiros, \& L. M. Viceira. (2010). Global Currency Hedging. The Journal of Finance, 65(1), 87-121. 10.1111/j.1540-6261.2009.01524.x.

Chen, C. F., \& C. W., Song Zan. (2009). Tourism expansion, tourism uncertainty and economic growth: New evidencefrom Taiwan and Korea. Tourism Management, 30, 812-818. https://doi.org/10.1016/j.tourman.2008.12.013.

Chen, J. H., \& I. H.Kuo. (2016). The study of exchange rate variability and pressures for Asian currency unit. Asia Pacific Management Review, 21(3), 135-141. https://doi.org/10.1016/j.apmrv.2016.01.003.

Chen,M.H., Soo Cheong, Jang, \& Y.J., Peng. (2011). Discovering Optimal Tourist Market Mixes. Journal of Travel Research, 50(6), 602-614. https://doi.org/10.1177/0047287510385464.

Dominguez, K. M. E., \& L. L., Tesar. (2006). Exchange rate exposure. Journal of International Economics, 68(1), 188-218. 10.1016/j.jinteco.2005.01.002.

Dumas, B. (1978 June). The theory of the trading firm revisited. Journal of Finance, 33(3), 1019-1029. https://doi.org/10.1111/j.1540-6261.1978.tb02041.x.

Elton, E., M. Gruber, S. Brown, \& W. Goetzmann. (2007). Modern Portfolio Theory and Investment Analysis. Wiley, New York.ISBN-13: 978-1118469941.

Fama, Eugene F., \& Kenneth R. French. (1993). Common risk factors in the returns on stocks and bonds. Journal of Financial Economics, 33(1), 3-56. https://doi.org/10.1016/0304-405X(93)90023-5. 
Fama, Eugene F., \& Kenneth R. French. (1995). Size and Book-to-Market Factors in Earnings and Returns. The Journal of finance, 50(1), 131-155. https://doi.org/10.1111/j.1540-6261.1995.tb05169.x.

Harris, L. (2003). Trading and Exchanges: Market Microstructure for Practitioners. Oxford University Press, Inc.ISBN-13: 978-0195144703.

He, J., \& L. K., Ng, (1998). The Foreign Exchange Exposure of Japanese Multinational $\begin{array}{lllll}\text { Corporations. } & \text { Journal } & \text { 733-753. }\end{array}$ https://doi.org/110.1111/0022-1082.295575.

Hodder, J. (1982). Exposure to exchange rate movements. Journal of International Economics, 13(3-4), 375-386. https://doi.org/10.1016/0022-1996(82)90065-4.

Huang, C.F., \& R. Litzenberger. (1988). Foundations for Financial Economics. North-Holland, New-York, 1988. ISBN: 0-13-500653-8.

Hurvich, C.M., \& C. L., Tsai, (1989 June). Regression and Time Series Model Selection in Small Samples. Biometrika 76(2), 297-307. https://doi.org/10.1093/biomet/76.2.297.

Huy, T. Q., (2016). The Linkage Between Exchange Rates and Stock Prices: Evidence from Vietnam. Asian Economic and Financial Review, 6(7), 363-373. https://doi.org/10.18488/journal.aefr/2016.6.7/102.7.363.373.

Jahan, N. (2016). Measuring Efficiency of Using Currency Derivatives to Hedge Foreign Exchange Risk: A Study on Advanced Chemical Industries (ACI) in Bangladesh. International Journal of Economics, Finance and Management Sciences, 4(2), 57-66. https://doi.org/10.11648/j.ijefm.20160402.14.

Jang, Soo Cheong, \& M.H., Chen. (2008). Financial portfolio approach to optimal tourist market mixes.Tourism Management, 29, 761-770. https://doi.org/10.1016/j.tourman.2007.09.003.

Jorion, P. (1990). The Exchange Rate Exposure of U.S. Multinationals. Journal of Business, 63(3), 331-345. https://doi.org/10.1086/296510.

Jorion, P. (1991). The Pricing of Exchange Rate Risk in the Stock Market. Journal of Financial and Quantitative Analysis, 26(3), 363-376.

Kim, H.Y., M. H., Chen, \& SooCheong, Jang. (2006). Tourism expansion andeconomic development: The case of Taiwan. Tourism Management, 27(5), 925-933. https://doi.org/10.1016/j.tourman.2005.05.011.

Kim, Y. Y. (2012). Stationary Vector Autoregressive Representation of Error Correction Models. Theoretical Economics Letters, 2, 152-156. https://doi.org/10.4236/tel.2012.22027.

Kim, Y. Y. (2013). Optimal Foreign Exchange Risk Hedging: A Mean-Variance Portfolio Approach. Theoretical Economics Letters, 3, 1-6. https://doi.org/10.4236/tel.2013.31001.

Kelilume, I. (2016). Exchange Rate Volatility and Firm Performance in Nigeria: A Dynamic 
panel Regression Approach. The Journal of Developing Areas, 50(6), 161-174. https://doi.org/10.1353/jda.2016.0134.

Koo, A. (1994). Estimation of foreign exchange exposure: an application to mining companies in Australia. Journal of International Money and Finance, 13(3), 342-363. https://doi.org/10.1016/0261-5606(94)90032-9.

Maloney, P. J. (1990). Management Currency Exposure: The Case of Western Mining. $\begin{array}{llll}\text { Journal of Applied } & \text { Corporate 29-34. }\end{array}$ https://doi.org/10.1111/j.1745-6622.1990.tb00185.x.

Markowitz, H.M. (1952). Portfolio Selection. Journal of Finance, 7(1), 77-91. https://doi.org/10.1111/j.1540-6261.1952.tb01525.x.

Min, C. K. (2013). Time-Specific Effects and a Test of the Tourism-Led Growth Hypothesis. Journal of Tourism and Hospitality Management, 1(3), 133-139. ISSN:2328-2169.

Morelli, D. (2007). Beta, size, book-to-market equity and returns: A study based on UK data. Journal of Multinational Financial Management, 17(3), 257-272. DOI:https://doi.org/10.1016/j.mulfin.2006.12.003.

Muller, A., \& W. F. C., Verschoor. (2006). Foreign exchange risk exposure: survey and suggestions. Journal of Multinational Financial Management, 16(4), 385-410. https://doi.org/10.1016/j.mulfin.2005.09.001.

Muriithi, J. G., W. M. Muturi, \& K. M. Waweru, (2016). The Effect of Market Risk on Financial Performance of Commercial Banks in Kenya. Journal of Finance and Accounting, 4(4), 225-233. https://doi.org/10.11648/j.jfa.20160404.18.

Nieh, C. C., \& H. F., Cho. (2017). The Effect of Exchange Rate Volatility on Stock Return in Taiwan Around Abenomics. Asian Economic and Financial Review, 7(4), 368-380. https://doi.org/10.18488/journal.aefr/2017.7.4/102.4.368.380.

Oh, C.O. (2005). The Contribution of Tourism Development to Economic Growth in the Korean Economy. Tourism Management, 26(1), 39-44. https://doi.org/10.1016/j.tourman.2003.09.014.

Patro, D.K., J. K., Wald, \& Y. Wu, (2002). Explaining exchange rate risk in world stock markets: A panel approach. Journal of banking \& finance, 26(10), 1951-1972. http://doi.org/10.1016/S0378-4266(01)00178-9.

Po, W. C., \& B. N. Huang. (2008). Tourism development and economic growth-a nonlinear approach. Physica A: Statistical Mechanics and its Applications, 387(22), 5535-5542. https://doi.org/10.1016/j.physa.2008.05.037.

Polodoo V., Seetanah B., and R. B., Sannassee, (2016). Exchange Rate Volatility and Manufacturing Trade: Evidence from Africa. The Journal of Developing Areas, 50(6), 133-148. https://doi.org/10.1353/jda.2016.0125.

Portnov, B.A., \& W. D. H. Li, (2013). Investigating the Effect of Global Economic Crisis on 


\section{Macrothink}

Asian Journal of Finance \& Accounting

ISSN 1946-052X

2017, Vol. 9, No. 1

Foreign Tourism to Taiwan. Journal of Tourism and Hospitality Management, 1(3), 113-132. http://www.davidpublishing.org/journals_info.asp?jId=1847.

Pritamani, M., D. Shome, \& V. Singal. (2005). Exchange Rate Exposure of Exporting and Importing Firms. Journal of Applied Corporate Finance, 17(3), 87-94. https://doi.org/10.1111/j.1745-6622.2005.00047.x.

Salifu, Z, K. A. Osei, \& C. K. D. Adjasi, (2007). Foreign exchange risk exposure of listed companies in Ghana. The Journal of Risk Finance, 8(4), 380-393. https://dx.doi.org/10.1108/15265940710777324.

Scheel, W. C. (1978). Comparisons of Riskiness as Measured by the Coefficient of Variation. The Journal of Risk and Insurance, 45(1), 148-152. https://doi.org/10.2307/251816.

Schnabel, J. A. (1989). Exposure to foreign exchange risk: A multi-currency extension. Managerial and Decision Economics, 10(4), 331-333. https://dx.doi.org/10.1002/mde.4090100411.

Schnabel, J. A., (1994). Real Exposure to Foreign Currency Risk. Managerial Finance, 20(8), 69-77. https://doi.org/10.1108/eb018487.

Sharpe, W. F. (1964). Capital Asset Pricing: A Theory of Market Equilibrium under Conditions of Risk. The Journal of Finance, 19(3), 424-447. https://doi.org/10.1111/j.1540-6261.1964.tb02865.x.

Smithson,C., \& B. J. Simkins. (2005). Does Risk Management Add Value? A Survey of the Evidence. Journal of Applied Corporate Finance, 17(3), 8-17. https://doi.org/10.1111/j.1745-6622.2005.00042.x.

Tsay, R.S. (2005). Analysis of Financial Time Series, Second Edition. John Wiley \& Sons, Inc. ISBN-13: 978-0-471-74618-8.

Wei, W. W.S. (2006). Time Series Analysis: Univariate and Multivariate Methods, Second Edition. Addison-Wesley. ISBN-13: 978-0321322166.

Witt, S. F., \& C. Witt. (1992). Modeling and Forecasting Demand in Tourism. Academic Press, London.ISBN: 0-127-60740-4.

Witt, S. F., \& C. Witt. (1995). Forecasting tourism demand: A review of empirical research. International Journal of Forecasting, 11(3), 447-475. https://doi.org/10.1016/0169-2070(95)00591-7. 